\title{
Mepiquat chloride promotes cotton lateral root formation by modulating plant hormone homeostasis
}

\author{
Qian $\mathrm{Wu}^{1,2}$, Mingwei $\mathrm{Du}^{1}$, Jie $\mathrm{Wu}^{3}$, Ning Wang ${ }^{4}$, Baomin Wang ${ }^{1}$, Fangjun $\mathrm{Li}^{1^{*}}$, Xiaoli $\operatorname{Tian}^{1}$ and Zhaohu Li ${ }^{1}$
}

\begin{abstract}
Background: Mepiquat chloride (MC), a plant growth regulator, enhances root growth by promoting lateral root formation in cotton. However, the underlying molecular mechanisms of this phenomenon is still unknown.

Methods: In this study, we used 10 cotton (Gossypium hirsutum Linn.) cultivars to perform a seed treatment with $M C$ to investigate lateral root formation, and selected a MC sensitive cotton cultivar for dynamic monitor of root growth and transcriptome analysis during lateral root development upon MC seed treatment.

Results: The results showed that MC treated seeds promotes the lateral root formation in a dosage-depended manner and the effective promotion region is within $5 \mathrm{~cm}$ from the base of primary root. MC treated seeds induce endogenous auxin level by altering gene expression of both gibberellin (GA) biosynthesis and signaling and abscisic acid (ABA) signaling. Meanwhile, MC treated seeds differentially express genes involved in indole acetic acid (IAA) synthesis and transport. Furthermore, MC-induced IAA regulates the expression of genes related to cell cycle and division for lateral root development.
\end{abstract}

Conclusions: Our data suggest that MC orchestrates GA and ABA metabolism and signaling, which further regulates auxin biosynthesis, transport, and signaling to promote the cell division responsible for lateral root formation.

Keywords: Cotton, Mepiquat chloride (MC), Lateral root, Phytohormone, Transcriptome

\section{Background}

The root system plays a pivotal role for plant growth by providing above ground mechanical support and controlling water and nutrient acquisition. Lateral roots, the major part of the root system in terms of root length and number, have crucial physiological capacities for water and nutrient uptake [1], and serve as the primary interface in response to heterogeneous soil environments [2]. Thus, the development of lateral roots has a decisive influence on both crop growth and harvest yield $[3,4]$.

The development of lateral roots is modulated by the regulatory networks integrating both genetic factors and endogenous hormones. Lateral root initiation originates from asymmetric cell division of xylem pole-pericycle

\footnotetext{
* Correspondence: lifangjun@cau.edu.cn

${ }^{1}$ College of Agronomy and Biotechnology, China Agricultural University, Beijing 100193, China

Full list of author information is available at the end of the article
}

cells induced by auxin-accumulation [5-10]. In plants, cell cycle and cell division progression are promoted by both the induction of positive regulators, such as cyclins (CYCs) and cyclin dependent kinases (CDKs), and the repression of negative regulators, including Kip-related proteins (KRPs) [11, 12]. The A-type CDKs and D-type CYCs complex play a critical role in cell cycle by regulating the G1-to-S transition. The G2-to-M checkpoint, regulating cell cycle progression to the mitotic phase, is mainly controlled by B-type CDKs and A- or B-type CYCs [13-15].

Auxin transport affects the asymmetric cell division [5, $6,16-18]$. Directional transport of auxin is controlled by the asymmetric distribution of auxin carriers, including the influx carrier, AUXIN TRANSPORTER PROTEIN 1 (AUX1) /like AUX1 (LAX), and the efflux carriers of the PIN-FORMED (PIN) family. AUX1 facilitates shootderived indole acetic acid (IAA) loading to the vascular 
transport system. LAXs mediates the formation of auxin gradient to generate acropetal auxin transport within inner tissues of the root apex and basipetal auxin transport within outer tissues of the root apex [19]. The PINS locates in a polar fashion, allowing directional auxin transport and the establishment of local auxin maxima and minima $[5,17,20]$.

Auxin/Indole-3-Acetic Acid (Aux/IAAs), AUXIN RESPONSE FACTOR (ARF), and SMALL AUXIN UP RNA (SAUR) are key members responsible for auxin signal transduction. IAA14/SLR (SOLITARY ROOT)ARF7-ARF19 and IAA12/BDL (BODENLOS)-ARF5 are important auxin signal modules involved in lateral root initiation [21-23]. Auxin-induced degradation of Aux/ IAA proteins releases ARF7 and ARF19 transcription factors to activate downstream gene expression for lateral root initiation [23-25]. LBD (LATERAL ORGAN BOUNDARIES DOMAIN) transcription factor family, function in lateral root formation, is identified as one of the direct downstream components of ARF7 and ARF19 [22, 25-27].

In addition to auxin, other plant hormones, including gibberellin (GA), abscisic acid (ABA), ethylene, and jasmonate (JA), also have influence on lateral root formation in an auxin-dependent manner. GA negatively affects lateral root formation partially by the regulation of polar auxin transport in Populus [28]. The ABA receptor PYL8 promotes lateral root growth by enhancing auxin signaling $[29,30]$. ABSCISIC ACID-INSENSITIVE 4 (ABI4) inhibits polar auxin transport by decreasing the expression of PIN1 to influence lateral root formation [31]. Ethylene affects auxin signaling and transport to regulate root development $[32,33]$. JA promotes lateral root formation by directly inducing the auxin biosynthesis and/or modulating PIN2 accumulation on the plasma membrane $[34,35]$.

A plant growth regulator mepiquat chloride (MC), a gibberellin synthetic growth retardant, blocks the entcopalyl diphosphate synthase (CPS) and ent-kaurene synthase $(K S)$ in the early steps of GA metabolism [36]. MC is a water-soluble organic molecule and regulates the plant growth upon soaking seeds or spraying leaves with this molecule [37]. MC has been commonly used in cotton production to shorten internode elongation, reduce main stem nodes, and decrease plant height, leading to a more compact plant architecture [38-41]. Apart from plant canopy manipulation, $\mathrm{MC}$ also enhances root growth by increasing numbers of lateral roots. However, the underlying mechanism is largely unknown.

In this study, a MC sensitive cotton cultivar was selected to perform the transcriptome analysis by RNAseq during lateral root development. We demonstrate that $\mathrm{MC}$ orchestrates $\mathrm{GA}$ and $\mathrm{ABA}$ metabolism, which further regulates auxin biosynthesis, transport, and signaling to control the cell division responsible for lateral root development.

\section{Results \\ MC promotes the development of lateral roots in cotton seedlings}

To study the effects of $\mathrm{MC}$ on the lateral root formation, we pretreated cotton seeds with $\mathrm{MC}$ and found that seeds treated with $\mathrm{MC}$ significantly increased the lateral root number of the tested cotton cultivars, with the exception of GX3 and L37 (Fig. 1a). Among these cultivars, K638 had the most significant response to MC on lateral root formation and was selected for further analysis. Different concentrations of $\mathrm{MC}$ were applied to detect lateral root formation of K638. The results showed that the induction of $\mathrm{MC}$ on lateral root formation was dosage dependent. The number of lateral roots had no obvious increase with $100 \mathrm{mg} / \mathrm{L} \mathrm{MC}$ treatment compared with $\mathrm{H}_{2} \mathrm{O}$ treatment. While, $28.5-37.7 \%$ and $30.1-45.8 \%$ induction of lateral root number were observed with 200 $\mathrm{mg} / \mathrm{L}$ and $400 \mathrm{mg} / \mathrm{L} \mathrm{MC}$ treatment compared with $\mathrm{H}_{2} \mathrm{O}$ treatment (Fig. 1b). After 8 days of MC treatment, K638 developed more and longer lateral roots compared with the control (Fig. 1c). The results showed that soaking seeds with MC promotes lateral root formation in cotton seedlings in a dosage dependent manner.

\section{Dynamic monitoring of MC effects on root growth}

To study the dynamic effects of MC on root growth, the cotton seedlings of $\mathrm{K} 638$ were cultured using the customized high-throughput robotic platform RhizoChamberMonitor [42] to monitor the dynamic growth of root systems. Primary root length was significantly increased compared to Control (the deionised water treatment). The primary root length was higher for MC treatment(Fig. 2a). For the lateral roots, both the total root length and root number of $\mathrm{MC}$ treatment were significantly more than that of Control (Fig. 2b, c). The increase rate of lateral root length upon $\mathrm{MC}$ treatment was significantly more than that of Control at seven DAT, while the increase rate of lateral root number was significantly higher for MC treatment from the day 5 (Fig. 2b, c). In addition, the BZL/PL ratio (Branching zone length /Primary root length) of $\mathrm{MC}$ treatment was significantly more than that of Control (Fig. 2d), and the increasing rate of BZL/PL ratio was higher before nine DAT.

In order to further identify the origin of lateral root induced by $\mathrm{MC}$ treatment in the primary root, the variations of lateral root number along $1 \mathrm{~cm}$ sections from root base to root tip in primary roots were quantified during the dynamic growth of root systems. The number of lateral roots was significantly more for $\mathrm{MC}$ treatment within $5 \mathrm{~cm}$ from the base of primary roots (Fig. 2e). In 


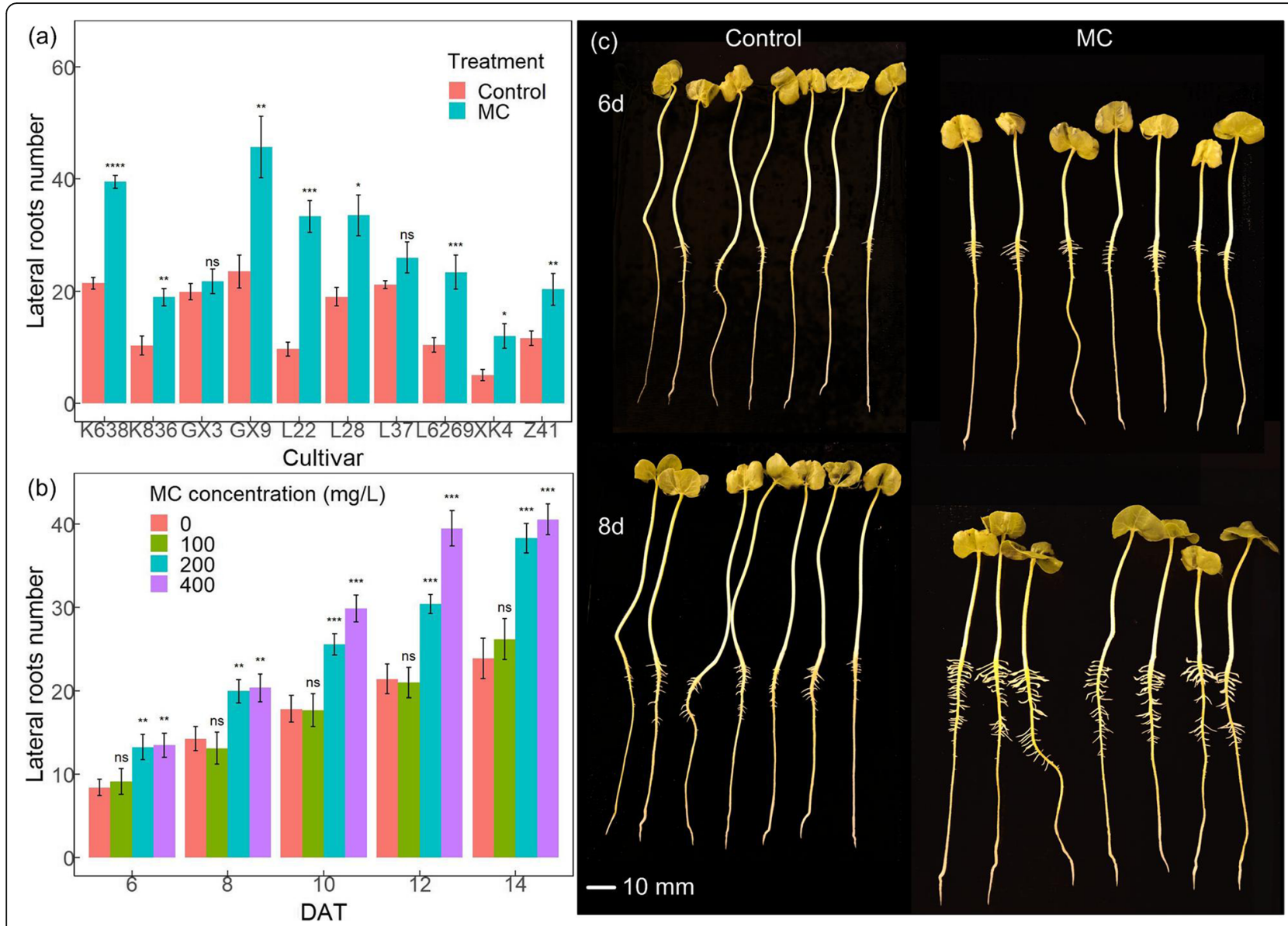

Fig. $1 \mathrm{MC}$ promotes lateral root development in cotton. a MC promotes lateral root development in different cotton cultivars. Seeds from 10 cotton cultivars were collected to detect their lateral root number 12 DAT of seeds soaked with deionised water (Control) or $400 \mathrm{mg} / \mathrm{L} \mathrm{MC} \mathrm{for} 12$ h. Images were acquired to quantify the lateral root number. $\mathbf{b}$ MC promotes lateral root development in a dosage-depended manner. Cotton seeds of $\mathrm{K} 638$ were treated with $100 \mathrm{mg} / \mathrm{L}, 200 \mathrm{mg} / \mathrm{L}$, and $400 \mathrm{mg} / \mathrm{L} \mathrm{MC}$. Images were acquired at indicated time points to quantify the lateral root number correspondingly. c Root phenotype of K638. Images were acquired at 6 and 8 days after MC treatment (DAT). Significant differences were assessed from three repeats by standard t-tests $\left({ }^{*} p<0.05,{ }^{* *} p<0.01\right.$, ${ }^{* * *} p<0.001$, $\left.{ }^{* * *} p<0.0001\right) .3$ replicates per treatment, 7 plants per replicate, a total of 21 seeds per treatment

addition, the lateral roots emerged much earlier with $\mathrm{MC}$ treatment than that of Control. The promotion effect of $\mathrm{MC}$ on lateral root formation was obvious before seven DAT. Together, soaking seeds with MC promotes the lateral root formation and advances the emerge-time of lateral roots.

\section{Transcriptome analysis of MC-treated cotton seeds}

To explore the dynamics of gene expression during cotton root development upon MC treatment, we performed RNA-seq analyses in cotton roots. An overview of the sequence assembly after Illumina sequencing was shown in Additional file 1: Table S1. Q20 and Q30 were above 96 and $92 \%$. The average error rate was less than $0.02 \%$. The percentage of low (FPKMs in the interval 13 ), medium (FPKMs in the interval 3-15), and high (FPKMs beyond 15) level expressed genes in control was $15,24.8$, and $15.5 \%$, respectively (Additional file 2: Table
S2). The relationship of transcriptome samples for Control and $\mathrm{MC}$ treatment at three time points were assessed by a principal component analysis (PCA) and hierarchical clustering (Additional file 6: Figure S1). The data indicate that three biological replicates of each treatment have strong correlation.

Eight patterns of gene expression along the three time points were identified in root tip and root middle region for $\mathrm{CK}$ and MC treatment by K-means clustering (Fig. 3). The similarity of gene expression levels was analyzed according to Euclidean distance. At root middle region, 50, 790 and 52,129 genes were assigned to eight clusters (K1 to K8) for Control (red numbers) and MC treatments (green numbers), respectively (Fig. 3a). In total, 29,226 genes $(56.1 \% / 57.5 \%$ in $\mathrm{MC} /$ Control treatment) exhibited the same expression pattern in both treatments (black numbers). At root tip, 39,719 and 45,143 genes were assigned to eight clusters for Control and $\mathrm{MC}$ 


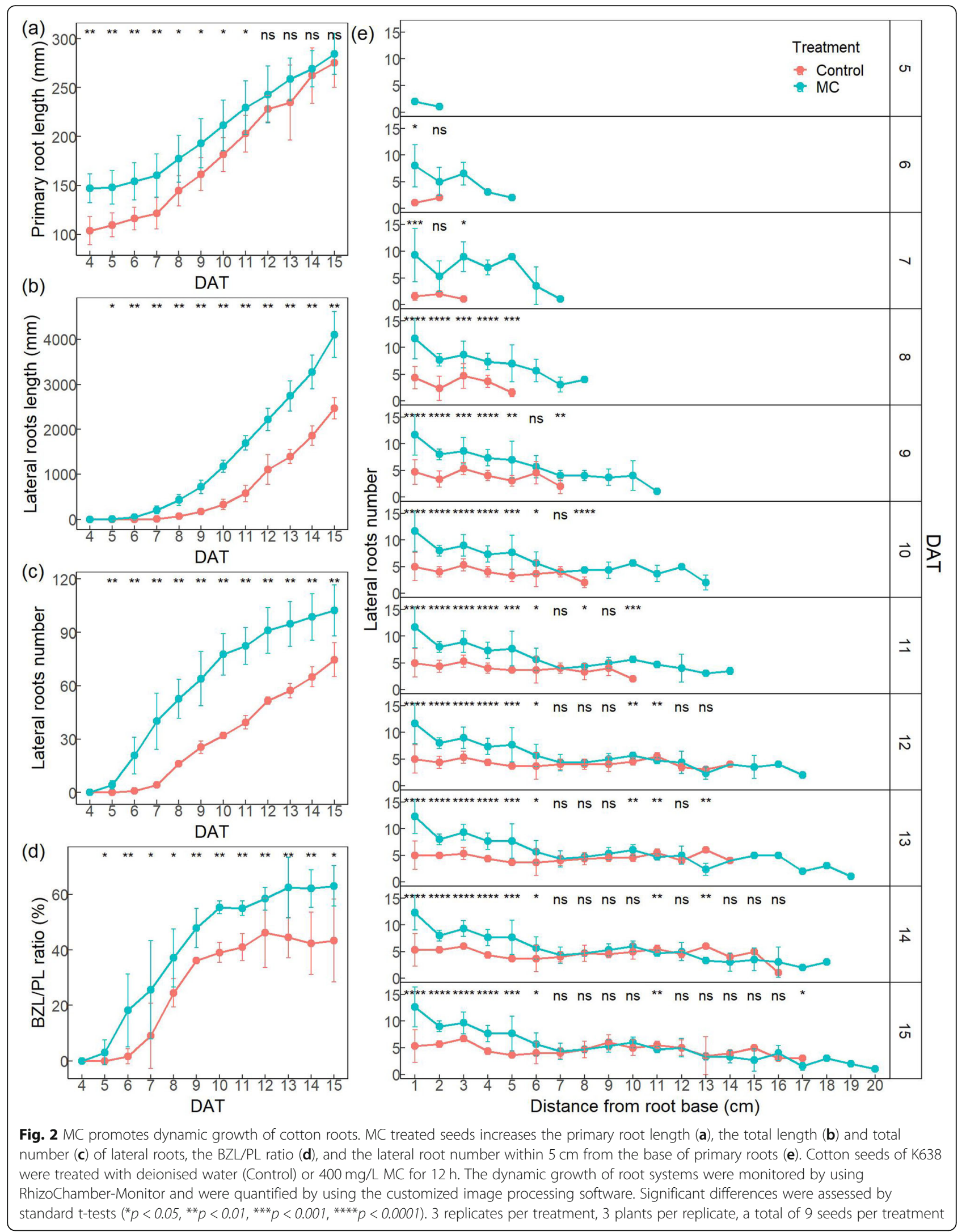



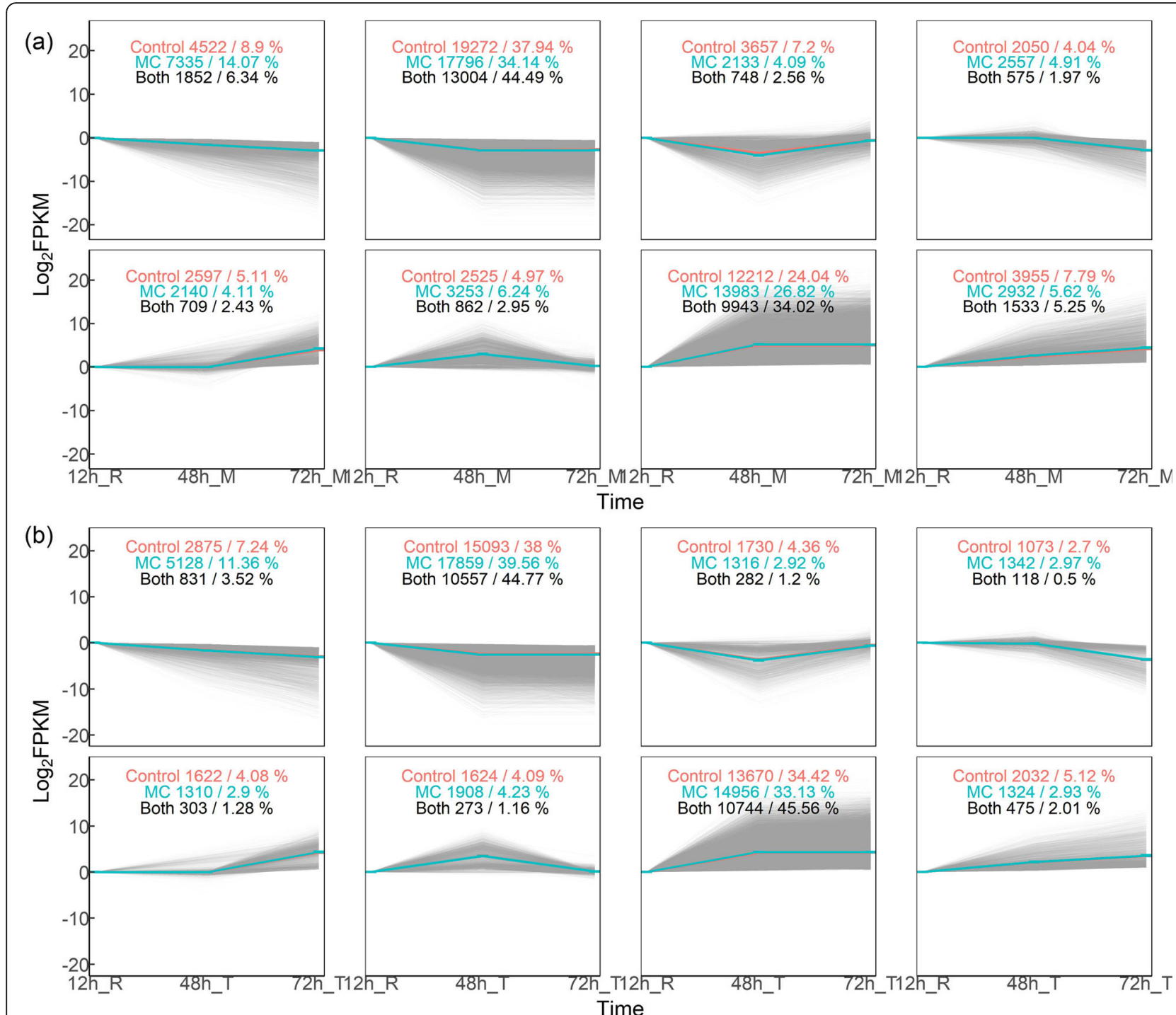

Fig. 3 The dynamics of gene expression during cotton root development. K-means clustering showing eight patterns of gene expression along three time points for the root middle region (a) and root tip (b), respectively. Cotton seeds of K638 were treated with deionised water (Control) or $400 \mathrm{mg} / \mathrm{L} \mathrm{MC}$ for $12 \mathrm{~h}$. The roots were sampled at 12, 48, and $72 \mathrm{~h}$ after treatment and subjected to RNA-seq analyses. "R" indicates the whole root, " $\mathrm{M}$ " indicates the root middle region (4 to $20-40 \mathrm{~mm}$ from the root tip), "T" indicates the root tip region (0 to $4 \mathrm{~mm}$ from the root tip). Numbers in red and green indicate the genes following the respective pattern for Control and $M C$ treatment, respectively. Numbers in black indicate genes displaying identical patterns in both treatments. 3 biological replicates per treatment, 30 roots per replicate

treatments, respectively (Fig. $3 \mathrm{~b}$ ). In total, 23,583 genes (51.9\%/59.3\% in MC/Control treatment) exhibited the same expression pattern in both treatments. Taking together, MC treated seeds change the transcriptome dynamics during cotton root development.

Differentially expressed genes (DEGs) were further determined between Control and MC soaking-seed treatment (Fig. 4). Overall 6113 DEGs (FDR $<5 \%$, $\left.\left|\log _{2} \mathrm{Fc}\right| \geq 1\right)$ in whole root at $12 \mathrm{~h}\left(12 \mathrm{~h} \_\mathrm{R}\right), 586$ DEGs in root middle region $\left(48 \mathrm{~h} \_\mathrm{M}\right), 413$ DEGs in root tip at $48 \mathrm{~h}(48 \mathrm{~h}$ T $), 1548$ DEGs in root middle region (72 h_M), and 874 DEGs in root tip at $72 \mathrm{~h}$
(72 h_T) were identified after MC treatment (Fig. 4a). Upon DPC treatment, 17 (0.2\%) DEGs were observed at all three time points; whereas 7386 (94.6\%) genes were differentially expressed at only one time point (Fig. 4b). In root tip, 36 (0.5\%) DEGs were observed at all three time points; whereas 6686 (95.2\%) genes were differentially expressed at only one time point (Fig. 4b). Among the common DEGs (FDR $<5 \%$, $\left.\left|\log _{2} \mathrm{Fc}\right| \geq 1\right)$ at all three time points in root middle region (Fig. 4c), four genes were down-regulated, and two genes were up-regulated, including CD48D gene encoding a cell division control protein; two bHLH 


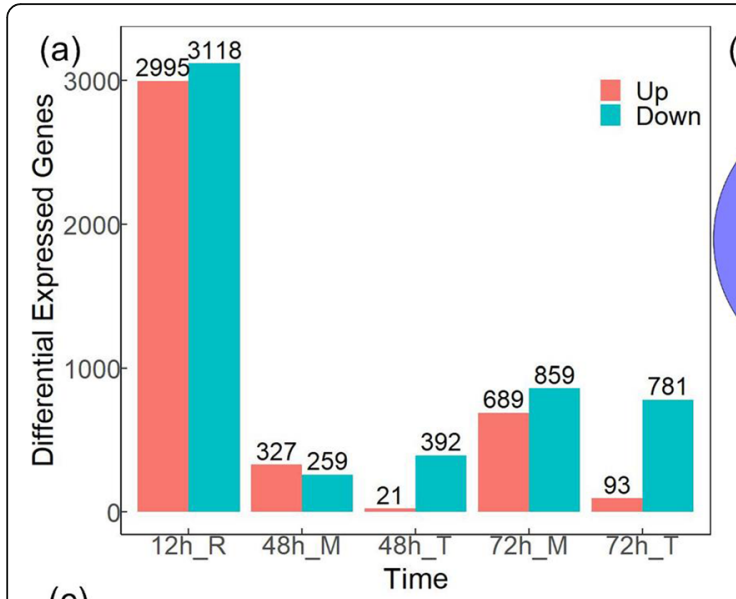

(c)

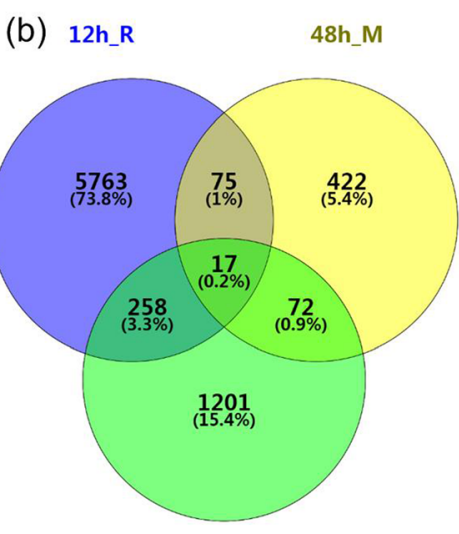

$72 \mathrm{~h} \_\mathrm{M}$

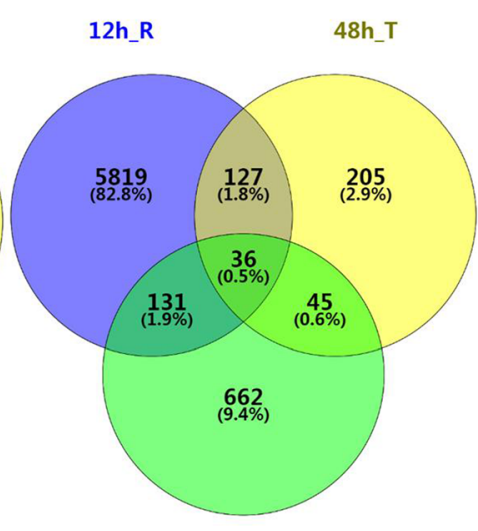

$72 \mathrm{~h}$ - $\mathrm{T}$

Root Tip

\begin{tabular}{|c|c|c|c|c|}
\hline & & & & \\
\hline $\begin{array}{l}\text { Gh_A04G1051- } \\
\text { Gh-D02G1153- }\end{array}$ & $\begin{array}{c}-1.3 \\
-1.14\end{array}$ & $\begin{array}{l}-1.3 \\
-1.25\end{array}$ & $\begin{array}{l}-3.27 \\
-1.05\end{array}$ & $\begin{array}{l}\text { A10A5 } \\
\text { RAV1 }\end{array}$ \\
\hline Gh-D09G1613- & 1 & -1.03 & -1.11 & \\
\hline $\mathrm{Gh}^{-} \mathrm{A} 07 \mathrm{G} 0244-$ & 1.06 & -1.06 & -1.11 & \\
\hline Gh-D05G0174- & 1.1 & -1.91 & -1.43 & NO93 \\
\hline Gh-D11G1830- & 1.13 & -1.02 & -1.35 & BCS1 \\
\hline Gh_Ä11G1138- & 1.15 & -1.26 & -1.2 & LEA34 \\
\hline $\mathrm{Gh}-\mathrm{A} 02 \mathrm{GO}$ & 1.16 & -2.5 & & \\
\hline Gh-DO & 1.18 & -1.77 & -1.77 & ETO1 \\
\hline Gh-D10G1 & 1.19 & -1.39 & -1.04 & \\
\hline Gh_D03G0420 - & 1.23 & -1.67 & -1.28 & \\
\hline $\mathrm{Gh}^{-\mathrm{D} 05 \mathrm{G} 1486-}$ & 1.23 & -1.09 & -1.64 & PDC1 \\
\hline $\mathrm{Gh}^{-} \mathrm{A} 02 \mathrm{GO}$ & 1.25 & -2.37 & -1.23 & $\mathrm{ADH} 1$ \\
\hline Gh-D12G2608- & 1.34 & -1.69 & -1.46 & SRO5 \\
\hline $\mathrm{Gh} A 03 \mathrm{G} 1802-$ & 1.34 & -1.43 & -1.25 & DNJ11 \\
\hline $\mathrm{Gh}^{-} \mathrm{A} 12 \mathrm{G} 2480-$ & 1.38 & -2.08 & -1.02 & SRO5 \\
\hline Gh_D & 1.38 & -1.63 & -1.78 & USPAL \\
\hline $\mathrm{Gh}-\mathrm{A}$ & 1.43 & -1.95 & -1.21 & USPAL \\
\hline $\mathrm{Gh}=\mathrm{AC}$ & 1.45 & -1.59 & -1.52 & \\
\hline $\mathrm{Gh}=\mathrm{A}$ & 1.45 & -1.3 & -1.47 & ABR1 \\
\hline $\mathrm{Gh}^{-\mathrm{DC}}$ & 1.46 & -1.98 & -1.35 & \\
\hline Gh_DC & 1.48 & -1.03 & -1.42 & P2A12 \\
\hline $\mathrm{Gh}^{-} \mathrm{A}$ & 1.48 & -1.61 & -1.61 & CATA1 \\
\hline $\mathrm{Gh}^{-} \mathrm{AC}$ & 1.49 & -1.11 & -1.35 & P2A12 \\
\hline D & 1.54 & -1.06 & -1.03 & RING1 \\
\hline Gh_DC & 1.57 & -1.19 & -1.18 & FLS2 \\
\hline $\mathrm{Gh}^{-} \mathrm{A} 1$ & 1.59 & -1.45 & -1.28 & P2B15 \\
\hline & 1.6 & -2.16 & -1.03 & \\
\hline $\mathrm{Gh}^{-} \mathrm{Ac}$ & 1.64 & -1.32 & -1.16 & \\
\hline Gh_D05G & 1.71 & -1.64 & -1.54 & PPSP2 \\
\hline Gh_D04G & 1.73 & -2.14 & -1.36 & RCA1 \\
\hline $\mathrm{Gh}^{-} \mathrm{A} 05 \mathrm{C}$ & 1.84 & -1.44 & -1.86 & PPSP2 \\
\hline & 1.89 & -1.9 & -1.67 & K6PF3 \\
\hline & 2.2 & -1.05 & -1.46 & MYB05 \\
\hline-1 & 2.45 & -1.81 & -1.26 & ZAT10 \\
\hline & & & -1.27 & \\
\hline & $12 \mathrm{~h} F$ & $48 \mathrm{~h}$ & $72 \mathrm{~h}$ & \\
\hline
\end{tabular}

Fig. 4 DEGs regulated by MC during root development in cotton. a The total number of up- and down-regulated DEGs in root middle region and root tip at three time points. b Venn diagram displaying DEGs and common genes upon soaking-seed treatment at three time points in root middle region and root tip. $\mathbf{c}$ Genes differentially expressed at all three time points in root middle region and root tip. Cotton seeds of K638 were treated with deionised water (Control) or $400 \mathrm{mg} / \mathrm{L} \mathrm{MC}$ soaking-seed for $12 \mathrm{~h}$. The roots sampled at 12, 48, and $72 \mathrm{~h}$ after treatment were subjected to RNA-seq analyses. " $\mathrm{R}$ " indicates the whole root, " $\mathrm{M}$ " indicates the root middle region (4 to $20-40 \mathrm{~mm}$ from the root tip), and "T" indicates the root tip region ( 0 to $4 \mathrm{~mm}$ from the root tip). The DEGs were controlled by FDR $<5 \%$ and $\left|\log _{2} F c\right| \geq 1$. Values in boxes are log $F$ c. 3 biological replicates per treatment, 30 roots per replicate

transcription factor genes (BH151) that modulate the balance between cellular proliferation and differentiation in root growth [43], were down-regulated at 12 $\mathrm{h}$ and $48 \mathrm{~h}$, while up-regulated at $72 \mathrm{~h}$. For the root tip (Fig. 4c), genes encoding auxin-induced protein A10A5 and two transcription factors AP2/ERF and B3 domain-containing RAV1 were down-regulated at all three time points; 34 genes were up-regulated at $12 \mathrm{~h}$ and down-regulated at $48 \mathrm{~h}$ and $72 \mathrm{~h}$, including ethylene-responsive transcription factor $A B R 1$, a negative regulator in ABA signaling pathway, myb-related transcription factor $M Y B 05$, ethylene-overproduction protein gene ETO1, and wall-associated receptor kinase gene WAK2. Most of these DEGs were plant hormones-related genes that are involved in root development. 


\section{GO and KEGG analysis}

The DEGs were assigned to different functional categories using GOseq $\mathrm{R}$ package. The DEGs between Control and MC treatments (q-value $<0.05$ ) were categorized into 54 functional groups. For biological process, 407, 405, 136, and 130 DEGs were enriched for the categories ' $\mathrm{R}$ biosynthetic process' (GO: 0032774), 'transcription, D-dependent' (GO:0006351), 'electron transport' (GO:0006118), and 'response to chemical stimulus' (GO:0042221) (Additional file 3: Table S3). For molecular function, 336, 64, and 64 DEGs were enriched for the categories 'oxidoreductase activity' (GO:0016491), 'sequence-specific D binding transcription factor activity'(GO:0003700), and 'nucleic acid binding transcription factor activity'(GO: 0001071) (Additional file 3: Table S3). The functional annotation and $\mathrm{GO}$ enrichment of the down-regulated and up-regulated DEGs at each time point of root middle region and root tip were shown in Additional file 7: Figure S2.

To identify the biological pathways involved in lateral root development upon MC treatment, we used KOBAS software to test the statistical enrichment of DEGs in KEGG pathways. Two thousand four hundred eighty-six DEGs between Control and MC treatment were assigned to 35 KEGG pathways (Additional file 8: Figure S3). Among them, 696 DEGs were assigned to metabolic pathways, 451 DEGs were assigned to biosynthesis of secondary metabolites, and 312 DEGs were assigned to plant hormone signal transduction.
MC modulates the expression profile and accumulation of multiple plant hormones

Phytohormones play a key role in plant growth and are closely related to root development. Next, we investigated the enriched functional category of hormone metabolism upon MC seed treatment and found that 274 DEGs were involved in hormone metabolism, signaling, or response (Fig. 5a). These DEGs were mainly related to ethylene (120 genes, 43.8\%), GA (57 genes, 20.8\%), auxin (41 genes, 15\%), ABA (25 genes, 9.1\%), and CTK (18 genes, 6.6\%). 89\% DEGs were related to ethylene and belonged to the $E R F / E F$ transcription factor family. In addition, nine DEGs were related to brassinosteroid (BR) and four DEGs were related to JA were observed.

To further confirm the involvement of these hormones, we detected the concentrations of GA, ABA, and IAA in cotton roots upon MC seed treatment. The data showed that treatment of MC induced IAA levels, but reduced GA and ABA levels in cotton roots at 5 days after treatment (DAT5) (Fig. 5b). The data indicates that $\mathrm{MC}$ could orchestrate hormone homeostasis.

\section{MC treatment alters the expression of GA-, ethylene-, and $A B A$-related genes}

Plant hormones have important influence on lateral root formation [30, 33, 35]. Specifically, GA-, ethylene-, and ABA-related DEGs were identified at each time points (the genes were controlled by $\mathrm{FDR}<5 \%$ ) (Fig. 6). GA biosynthesis genes CPS, GA20OX, and GA3OX were down-regulated by MC treatment. While GA2OX, a gene

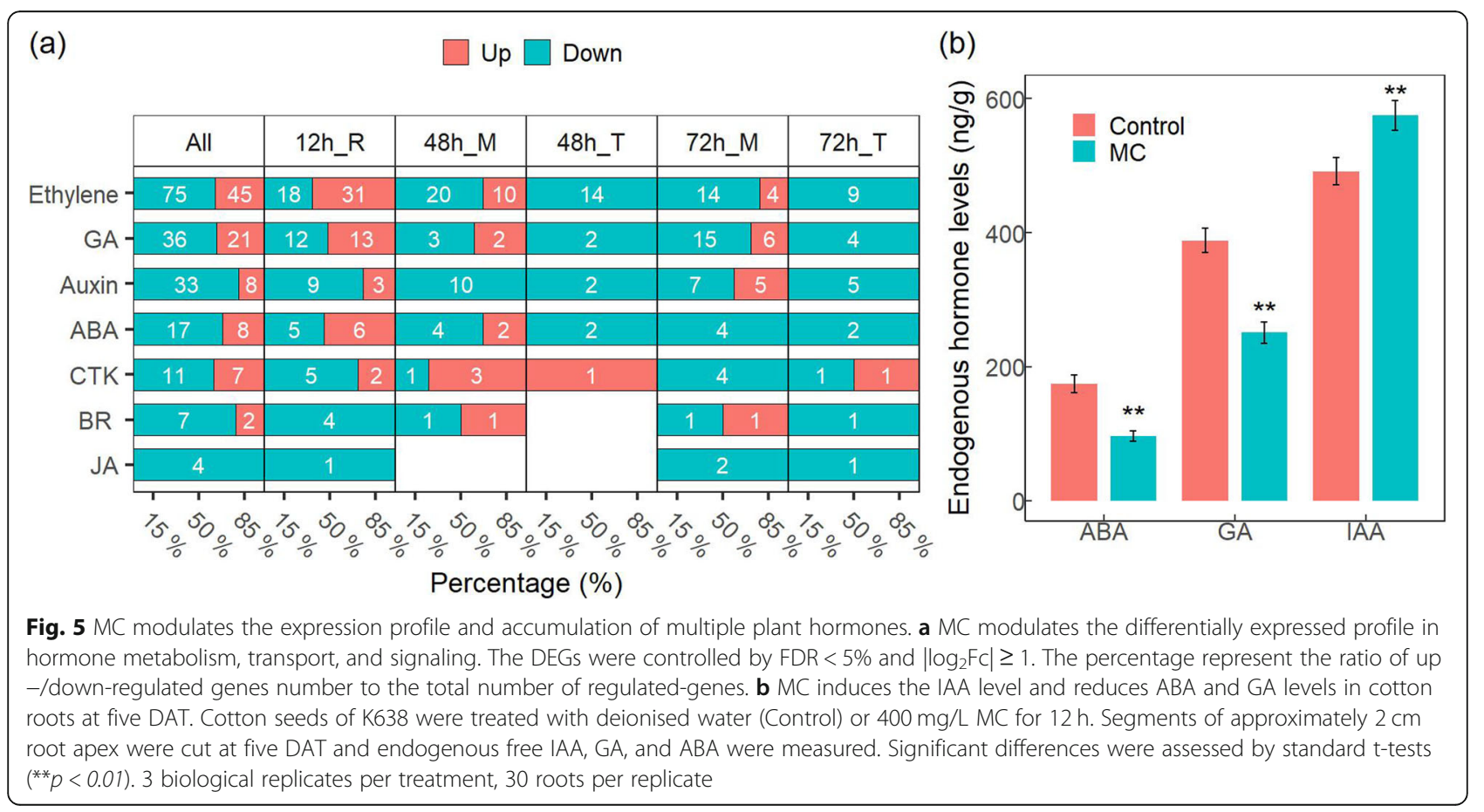


Up $\square$ Down

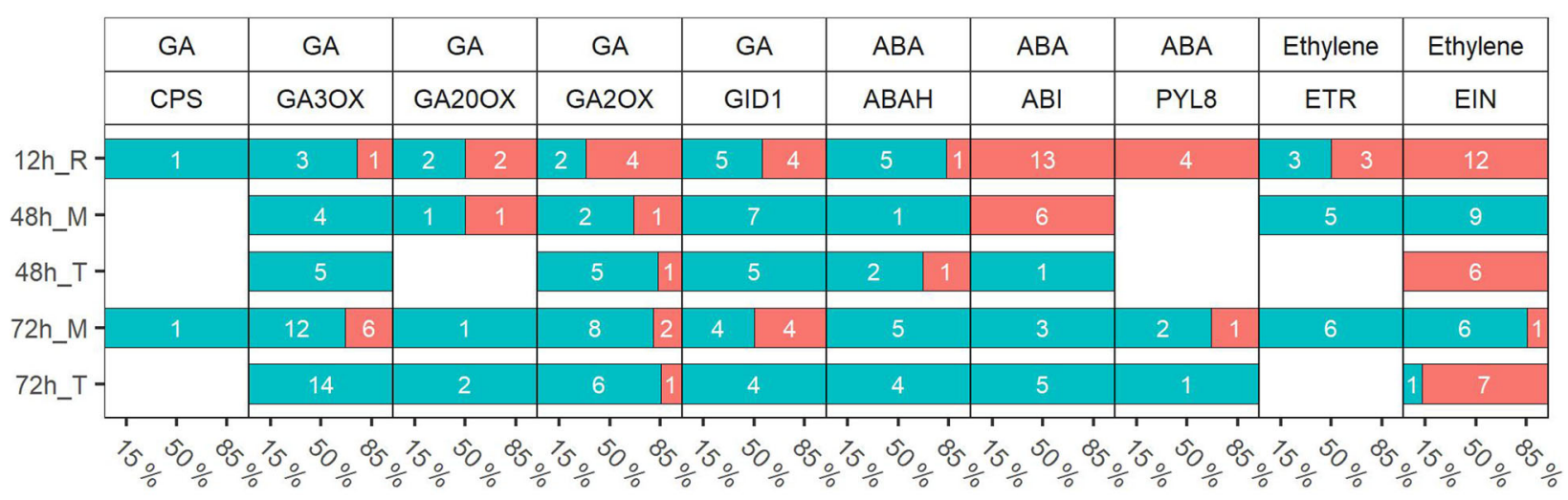

Percentage (\%)

Fig. $6 \mathrm{MC}$ regulates the expression of GA-, ethylene-, and ABA -related genes. The DEGs were controlled by FDR $<5 \%$. Cotton seeds of K638 were treated with deionised water (Control) or $400 \mathrm{mg} / \mathrm{L} \mathrm{MC}$ for $12 \mathrm{~h}$. The roots sampled at 12,48 , and $72 \mathrm{~h}$ after treatment were subjected to RNA-seq analyses. " $\mathrm{R}$ " indicates the whole root, " $\mathrm{M}$ " indicates the root middle region (4 to $20-40 \mathrm{~mm}$ from the root tip), and " $\mathrm{T}$ " indicates the root tip region ( 0 to $4 \mathrm{~mm}$ from the root tip). White digit indicated the gene number. The percentage represent the ratio of up-/down-regulated genes number to the total number of regulated-genes. 3 biological replicates per treatment, 30 roots per replicate

involved in GA catabolism, was up-regulated at $12 \mathrm{~h}$. The GA receptor GIBBERELLIN INSENSITIVE DWARF1, GID1 was down-regulated. GA plays negative roles in lateral root formation. Consistently, our results showed that MC represses GA biosynthesis and signaling during lateral root formation. We also found that ethylene receptor ETRs and Ethylene-insensitive protein $(E I N)$ family genes were down-regulated in the root middle region at $48 \mathrm{~h}$ and $72 \mathrm{~h}$. Moreover, we observed that the $A B A H$ gene family, involved in the oxidative degradation of ABA, was down-regulated. While, ABSCISIC ACID-INSENSITIVE3/4/5 (ABI3/4/5) and ABA receptor PYL8, both which function in ABA signaling, were up-regulated at $12 \mathrm{~h}$.

\section{MC modulates the expression of auxin-related genes}

Auxin is the major hormone to control lateral root development. Auxin-related DEGs that belonged to different families were identified at each time points (Fig. 7, Additional file 4: Table S4). For the auxin synthesis

\begin{tabular}{|c|c|c|c|c|c|c|c|c|c|c|c|}
\hline 12h_R - & \multicolumn{11}{|c|}{$\square$ Up $\square$ Down } \\
\hline \multirow{3}{*}{ 12h_R } & Synthesis & Synthesis & Synthesis & Transport & Transport & Signaling & Signaling & Signaling & Signaling & Signaling & Signaling \\
\hline & AAO & YUC & $\mathrm{GH} 3$ & LAX & PIN & Aux/IAA & ARF & LBD & $\mathrm{E} 2 \mathrm{~F}$ & MYB & WRKY \\
\hline & 1 & \begin{tabular}{l|l}
1 & 1 \\
\end{tabular} & \begin{tabular}{l|l}
7 & 8 \\
\end{tabular} & 14 & 10 & $65 \quad 12$ & \begin{tabular}{|l|l|}
9 & 25 \\
\end{tabular} & 3 & 1 & \begin{tabular}{|l|l|}
10 & 18 \\
\end{tabular} & 7 \\
\hline & 2 & 2 & \begin{tabular}{|l|l|}
3 & 6 \\
\end{tabular} & 4 & 2 & \begin{tabular}{l|l|}
40 & 10 \\
\end{tabular} & 18 & 2 & 1 & 8 & \begin{tabular}{l|l}
1 & 1 \\
\end{tabular} \\
\hline 48h_T - & & 3 & 8 & 3 & & \begin{tabular}{l|l|}
27 & 10
\end{tabular} & \begin{tabular}{|l|l|}
2 & 2 \\
\end{tabular} & & & 13 & \\
\hline 72h_M - & \begin{tabular}{l|l}
1 & 1 \\
\end{tabular} & \begin{tabular}{|l|l|}
2 & 1 \\
\end{tabular} & \begin{tabular}{l|l}
7 & 8 \\
\end{tabular} & 8 & 2 & \begin{tabular}{l|l|}
30 & 10 \\
\end{tabular} & \begin{tabular}{|l|l|}
3 & 12 \\
\end{tabular} & 1 & 1 & 9 & 2 \\
\hline $72 \mathrm{~h} \_\mathrm{T}-$ & $\frac{3}{1}$ & \begin{tabular}{|l|l|}
1 & 1 \\
1 & 5 \\
\end{tabular} & 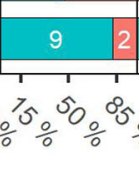 & \begin{tabular}{|l|l|}
1 & 3 \\
1 & 1 \\
7 & 5
\end{tabular} & $\begin{array}{l}2 \\
v_{0} \\
v_{0}\end{array}$ & \begin{tabular}{|l|l|}
29 & 7 \\
1 & 1 \\
50 & 0
\end{tabular} & $\begin{array}{|ll|}13 & 3 \\
& 1\end{array}$ & 1 & $\frac{1}{5}$ & $\frac{14}{s_{0}^{5}}$ & $\frac{1}{v_{0}^{v_{0}} \hat{0}_{\frac{0}{0}} \delta_{s}}$ \\
\hline $\begin{array}{l}\text { Fig. } 7 \mathrm{MC} \\
\text { deionised } \\
\text { indicates } \\
\text { from the } \\
\text { number } 0\end{array}$ & $\begin{array}{l}\text { C modulates } \\
\text { water (Con } \\
\text { the whole r } \\
\text { root tip). Wh } \\
\text { of regulated- }\end{array}$ & $\begin{array}{l}\text { the expressi } \\
\text { trol) or } 400 \text { n } \\
\text { oot, "M" indi } \\
\text { iite digit ind }\end{array}$ & $\begin{array}{l}\text { ion of the au } \\
\mathrm{ng} / \mathrm{LC} \text { M for } \\
\text { cates the roc } \\
\text { icated the ge } \\
\text { logical replic }\end{array}$ & $\begin{array}{l}\text { uxin-related } \\
12 \mathrm{~h} \text {. The ro } \\
\text { ot middle reg } \\
\text { ene number. } \\
\text { cates per trea }\end{array}$ & $\begin{array}{l}\text { yenes. The D } \\
\text { ots sampled } \\
\text { yion ( } 4 \text { to } 20 \\
\text { The percent } \\
\text { tment, } 30 \text { ro }\end{array}$ & $\begin{array}{l}\text { EGs were cor } \\
\text { at } 12,48 \text {, an } \\
-40 \mathrm{~mm} \text { from } \\
\text { age represer } \\
\text { ots per repli }\end{array}$ & $\begin{array}{l}\text { ntrolled by } \\
\mathrm{dd} 72 \mathrm{~h} \text { after } \\
\mathrm{m} \text { the root ti } \\
\mathrm{nt} \text { the ratio } \\
\text { icate }\end{array}$ & $\begin{array}{l}\text { FDR < } 5 \% \text {. C } \\
\text { treatment } \\
\text { ip), and "T" in } \\
\text { of up-/dow }\end{array}$ & $\begin{array}{l}\text { otton seeds } \\
\text { vere subjecte } \\
\text { ndicates the } \\
\text { n-regulated }\end{array}$ & $\begin{array}{l}\text { of K638 were } \\
\text { ed to RNA-se } \\
\text { root tip regi } \\
\text { genes numb }\end{array}$ & $\begin{array}{l}\text { treated with } \\
\text { q analyses. " } \\
\text { on }(0 \text { to } 4 \text { m } \\
\text { er to the tot }\end{array}$ \\
\hline
\end{tabular}


DEGs, $A A O 2$, encoding the enzyme for oxidizing indole-3acetaldehyde to IAA, was up-regulated at $12 \mathrm{~h}$ and $48 \mathrm{~h}$ in the root middle region; YUC family genes, which encode flavin monooxygenase-like proteins that catalyze a ratelimiting step in IAA biosynthesis, were up-regulated at 48 $\mathrm{h}$, indicating that $\mathrm{MC}$ could induce auxin biosynthesis. GH3 family genes, which encode IAA-amido synthetases, were mostly down-regulated at $48 \mathrm{~h}$ and $72 \mathrm{~h}$ in root tip. Meanwhile, auxin transport genes, like LAX and PIN family genes were down-regulated at $12 \mathrm{~h}$ and $48 \mathrm{~h}$, but upregulated at $72 \mathrm{~h}$, indicating that $\mathrm{MC}$ may gradually regulate auxin transport to promote lateral root formation. DEGs related to auxin signaling, like negative regulator Aux/IAA family genes, were down-regulated by MC treatment. Moreover, over half of the $A R F$ family genes were up-regulated at $12 \mathrm{~h}$ in root and at $48 \mathrm{~h}$ and $72 \mathrm{~h}$ in the root middle region. The $L B D s$ and E2Fs transcription factors, two downstream components of $A R F$, were up-regulated at $12 \mathrm{~h}$ in root and at $48 \mathrm{~h}$ and $72 \mathrm{~h}$ in the root middle region. In addition, some auxin-related transcription factors, like WRKY and MYB, were up-regulated at $12 \mathrm{~h}$, suggesting that the auxin signaling was enhanced upon MC treatment in the lateral root initiation zone.

\section{MC promotes lateral root development through regulating cell cycle and division}

Cell proliferation and differentiation regulate lateral root initiation. Genes known to be involved in cell cycle and cell division were identified at root middle region and root tip, respectively (Fig. 8a). At the root middle region, two cell division cycle protein gene family, CDC48 and $C D 48 D$, were up-regulated at all three time points; one cyclin-dependent kinase gene, $C D K G 2$, was also upregulated by $\mathrm{MC}$ treatment. Specifically, cell cycle and cell division related DEGs that belonged to different families were identified at each time points (Fig. 8b). Most of the CYCs family genes, which are involved in the control of the cell cycle at the G1/S (start) transition, were up-regulated at $72 \mathrm{~h}$. Majority of $C D K$ genes were up-regulated at $72 \mathrm{~h}$ and $K R P$ genes were downregulated at $12 \mathrm{~h}$ by $\mathrm{MC}$ treatment. Most $C D C$ family genes, peptidyl-prolyl isomerase (PPIase) family genes (CYP and FKBP), and the structural maintenance of chromosomes protein gene $(S M C)$ was up-regulated at $72 \mathrm{~h}$. The results suggest that MC promotes lateral root formation by regulating genes related to cell cycle and cell division.

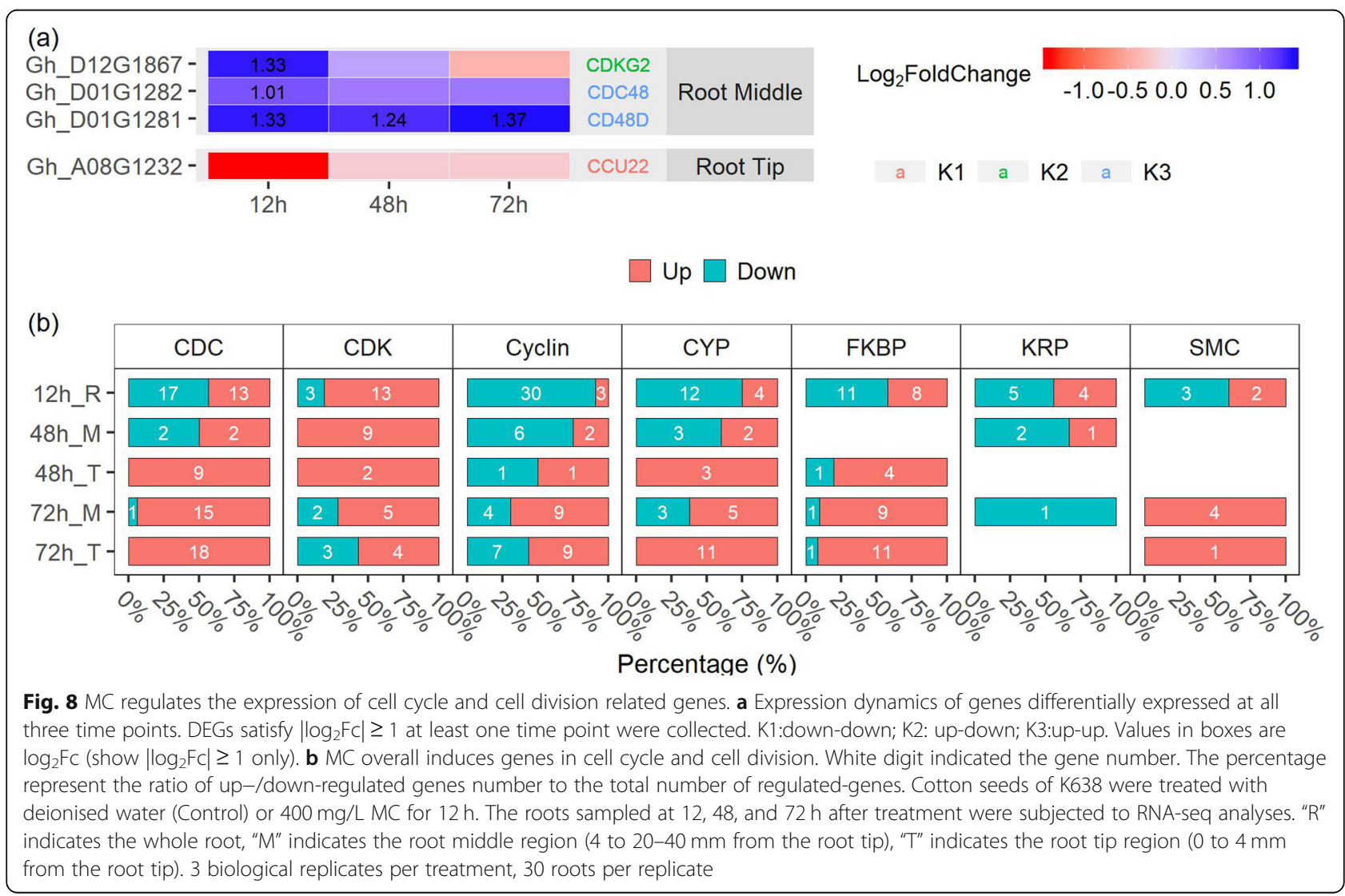




\section{Discussion}

\section{MC promotes cotton lateral root formation}

$\mathrm{MC}$ is a commonly used plant growth regulator in cotton production and enhances root growth by increasing the number of lateral roots and root biomass [37]. However, the underlying molecular mechanism on how $\mathrm{MC}$ promotes lateral root initiation in cotton is unclear. Our studies show that soaking seeds with MC significantly promotes the cotton lateral root formation in a dosagedepended manner (Fig. 1a, b). With RNA-Seq analysis, large number of DEGs, especially genes related to hormone metabolism and signaling, were determined during lateral root formation with MC treated seeds.

\section{MC mediates the crosstalk among GA, ABA, and IAA during lateral root formation}

Inhibitors of GAs biosynthesis, such as paclobutrazol, can enhance lateral root formation in tomato (Solanum lycopersicum) [44], pepper (Capsicum chinense) [45], and several tree species [46]. Mutants defective in GA biosynthesis or signaling were found to have stimulated lateral root formation [28, 44, 47]. MC promotes lateral root development likely via the regulation of endogenous gibberellin. Here, the RNA-seq results showed that MC down-regulates GA biosynthesis genes, like CPS, GA20oxs, and GA3ox, while up-regulates GA catabolism gene GA2ox (Fig. 6 and Additional file 9: Figure S4). Consistently, the GA levels in root was significantly lower for MC treated seeds compared with the control (Fig. 5b).

The crosstalk of GA and other hormones, including auxin and ABA, play important roles in modulation of lateral root development [28]. GA receptor GID1 induces the degradation of DELLA proteins, and further regulates the expression of XERICO, an inducer of ABA biosynthesis [35, 48]. Thus, endogenous ABA levels may be increased by $\mathrm{MC}$ treatment at the stage of seed development. GA negatively affects lateral root formation partially by the regulation of polar auxin transport in Populus [28]. Our results show that MC treatment significantly increases auxin levels and reduces ABA levels in root tissues at five DAT (Fig. 5b), consistent with the result that GA affects lateral root formation through auxin-mediated pathway or direct down-regulation of ABA biosynthesis [28].

Auxin is known to be the critical phytohormone involved in regulating lateral root development [23]. Auxin maxima in the lateral root initiation zone is a key factor for the formation of lateral root primordial, which is maintained via the activation of auxin biosynthesis and transport $[5,6,16-18]$. ABA could influence lateral root formation by regulating auxin signaling and transport [29-31]. However, there are contradictory understandings of $\mathrm{ABA}$ effects on lateral root formation. The ABA receptor PYL8 promotes lateral root growth by the activation of MYB44 to induce auxin signaling [29, 30]. In contrast, Shkolnik-Inbar and Bar-Zvi reported that ABA inhibits lateral root formation by regulating auxin transport [31]. $A B I 4$ inhibits polar auxin transport in the root by decreasing the expression of PIN1; and the expression of $A B I 4$ is enhanced by $\mathrm{ABA}$ and repressed by auxin. In our study, PYL8 and MYB44 were up-regulated at $12 \mathrm{~h}$ (Figs 6, 7 and Additional file 9: Figure S4); $A B I 5$ was down-regulated. Meanwhile, PINs were up-regulated at $72 \mathrm{~h}$ (Fig. 7). Thus, it is likely that MC treatment enhances auxin signaling via up-regulating ABA receptor $P Y L 8$, and enhances auxin signaling via down-regulating $A B I s$ to promote lateral root growth. Negi et al. [32] reported that etr 1 or ein 2 mutants in ethylene signaling increase lateral root formation via the crosstalk with auxin signaling and transport pathways. Consistently, our data show that ETR family genes were down-regulated at 48 $\mathrm{h}$ and $72 \mathrm{~h}$. Most EIN family genes were down-regulated in the root middle region (Fig. 6). Taken together, these results provide evidence that $\mathrm{MC}$ acts as an important regulator of lateral root development in a hormone crosstalk manner.

\section{MC directly regulates auxin metabolic, transport, and signaling}

Auxin biosynthesis mediated by YUC or TAA promotes lateral root formation [49]. Overexpression of $Y U C 1 / 6$ and TAA1 increases IAA concentrations along with enhanced lateral root formation in Arabidopsis thaliana [49]. The auxin efflux regulators PIN and auxin influx carrier AUX1 mediate auxin transport in lateral root formation [5]. In our study, YUC family genes were up regulated by $\mathrm{MC}$ treatment at $48 \mathrm{~h}$ (Fig. 7). In addition, most auxin influx carriers LAX family genes and auxin efflux carriers PIN family genes were up-regulated at $72 \mathrm{~h}$ after $\mathrm{MC}$ treatment (Fig. 7 and Additional file 11: Figure S6). The IAA levels in roots was significantly higher for MC treated seeds (Fig. 5b). Thus, MC treated seeds could promote lateral root formation by directly regulating the expression of auxin biosynthesis and transport genes.

As the most important members of auxin signal transduction, $A u x / I A A s$ family genes play a role in lateral root formation [21, 50-52]. Several Aux/IAA-ARF modules have been implicated in driving lateral root formation [25]. The IAA28-ARF5/6/7/19 module is specific for priming cell specification $[6,53]$. The IAA14 -ARF7/19 module and IAA12-ARF5 module are specific for lateral root initiation and patterning [21-23]. The repression of $I A A 12$ and IAA14 induce ARF5 and ARF7/19 gene expression to activate the cell cycle and form a lateral root primordial [25]. In our study, most Aux/IAA family genes were down-regulated by $\mathrm{MC}$ treatment, including 
IAA14, IAA18, and AUX28 (Fig. 7 and Additional file 9: Figure S4, Additional file 11: Figure S6). However, some ARF family genes, like ARF5/6/7 and ARF19 in the root middle region were up-regulated (Fig. 7 and Additional file 9: Figure S4, Additional file 11: Figure S6). The $L B D$ transcription factor family is a downstream component of $A R F 7$ and $A R F 19$, and is involved in various rootrelated developmental processes [54-56]. LBD16, $L B D 18, L B D 29$, and $L B D 33$ have the cooperative regulation on the initiation and emergence of lateral root in Arabidopsis [26, 57, 58]. In this study, LBD16 and $L B D 18$ were up-regulated by MC treatment (Fig. 7 and Additional file 9: Figure S4, Additional file 11: Figure S6). $L B D 18 / L B D 33$ dimer could further regulates $E 2 F a$ and $E 2 F b$ gene expression which are two transcriptional activator in cell cycle to stimulate cell entry into both Sand M-phases [27, 59, 60]. Together, the data indicate that $\mathrm{MC}$ activates auxin signaling mainly via the induction of auxin-related transcription factors during lateral root formation.

\section{MC induces genes in cell cycle during lateral root formation}

The formation of lateral root is controlled by auxinmediated cell cycle and cell division. The auxindependent cell cycle is mainly controlled by CDKA and CDKB [61]. The activity of CDK is largely determined by association with different cyclin partner CYCs $[11,15$, 62]. Auxin and CTK increase the expression level of $C Y C D$ to activate CDKA, indicating their important role for mitotic activity in cell division [63-65]. In our study, most $C Y C s$ and $C D K$ family genes, including $C Y C A / B$ and $C D K B$, were up-regulated at $72 \mathrm{~h}$ after MC treatment. KRP, as a negative regulator at early lateral root initiation by blocking the G1-to-S transition, is transcriptionally regulated by auxin $[11,62]$. Here, we showed that KRP was down-regulated by MC treatment of seeds (Fig. 8b and Additional file 10: Figure S5). CDC45 is required for initiation of chromosomal DNA replication. It acts at the origin of replication and in minichromosome maintenance $[66,67]$. The peptidylprolyl isomerase (PPIase) family genes (CYP and FKBP) are essential for regulation of mitosis and cell growth [68]. The chromosomal structure maintains SMC is involved in cell cycle and DNA repair progression [69]. In this study, CDCs, FKBP, CYP, and SMC were all upregulated at $72 \mathrm{~h}$ after $\mathrm{MC}$ treatment (Fig. $8 \mathrm{~b}$ and Additional file 10: Figure S5), suggesting that $\mathrm{MC}$ induces lateral root formation by transcriptional regulation of the cell cycle.

\section{Conclusion}

In general, the promoting effect of $\mathrm{MC}$ on lateral root formation is dosage dependent and shows a limited, effective duration and location in cotton roots. Here, we identified that MC soaking-seed inhibits GA biosynthesis and reduces GA level by regulating the genes in GA synthesis and signaling. The genes in ABA signaling are further affected because of the MC treated seeds also affect auxin signaling and transport by regulating genes involved in auxin biosynthesis, transport, and signaling, and the cell cycle and division process, have transcriptional change and were selected for further confirmation by qRT-PCR (Additional file 11: Figure S6). These results confirm that MC orchestrates phytohormonedependent transcriptional networks during lateral root initiation (Fig. 9). Ethylene alters rooting by modulation of polar auxin transport upon MC treatment. Moreover, $\mathrm{MC}$ affects the auxin biosynthesis and auxin transport by regulating the expression of YUC, AAO, PIN and $L A X$ genes, suggesting that $\mathrm{MC}$ affects lateral root formation by promoting the cooperation of auxin with other phytohormones. Furthermore, with the activation of auxin signaling, the downstream targets, $L B D s$ and $E 2 F s$, were regulated to control the cell cycle progression. The repression of KRPs, and the induction of $C Y C s, C D K s, C D C s, F K B P, C Y P$, and $S M C$, activate the cell cycle and promote cell division progression. The results indicate that MC promotes lateral root formation likely through the induction of auxin metabolism and signaling to active cell cycle and division processes via regulating hormone homeostasis.

\section{Materials and methods}

\section{Plant materials, experimental set-up and growth conditions}

Ten cotton (Gossypium hirsutum Linn.) cultivars K638, K836, Lu22 (L22), Lu28 (L28), Lu37 (L37), Lu6269 (L6269), Guoxin3 (GX3), Guoxin9 (GX9), Xinkang4 (XK4), and Zhong41 (Z41) were used in this study (provided by Hebei Guoxin Rural Technical Service Association, Institute of Cotton Research of CAAS, and Cotton Research Center, Shandong Academy of Agricultural Sciences). Seeds were surface-sterilized by soaking in $15 \% \mathrm{H}_{2} \mathrm{O}_{2}$ for $15 \mathrm{~min}$, then rinsed with tap water. Two soaking experimental treatments were designed. Experiment 1: Seeds of 10 cotton cultivars were soaked in deionised water (Control) or Mepiquat chloride (MC, purity 97\%, Hebei Guoxin ahadzi Biological Technology Co., Ltd. Hejian, Hebei, China) solution (400 mg/L) at $30^{\circ} \mathrm{C}$ for $12 \mathrm{~h}$; Experiment 2: Seeds of $\mathrm{K} 638$ were soaked in deionised water (Control) or different concentrations of MC solution $(100,200$, and $400 \mathrm{mg} / \mathrm{L})$ at $30{ }^{\circ} \mathrm{C}$ for $12 \mathrm{~h}$.

Seeds were germinated between two wetted germination papers $(25 \mathrm{~cm} \times 38 \mathrm{~cm}$, Cat.No OP1015, Hoffman Manufacturing Inc., Albany, OR 97321, USA) with a backboard for support. Seven seeds were arranged at 6 


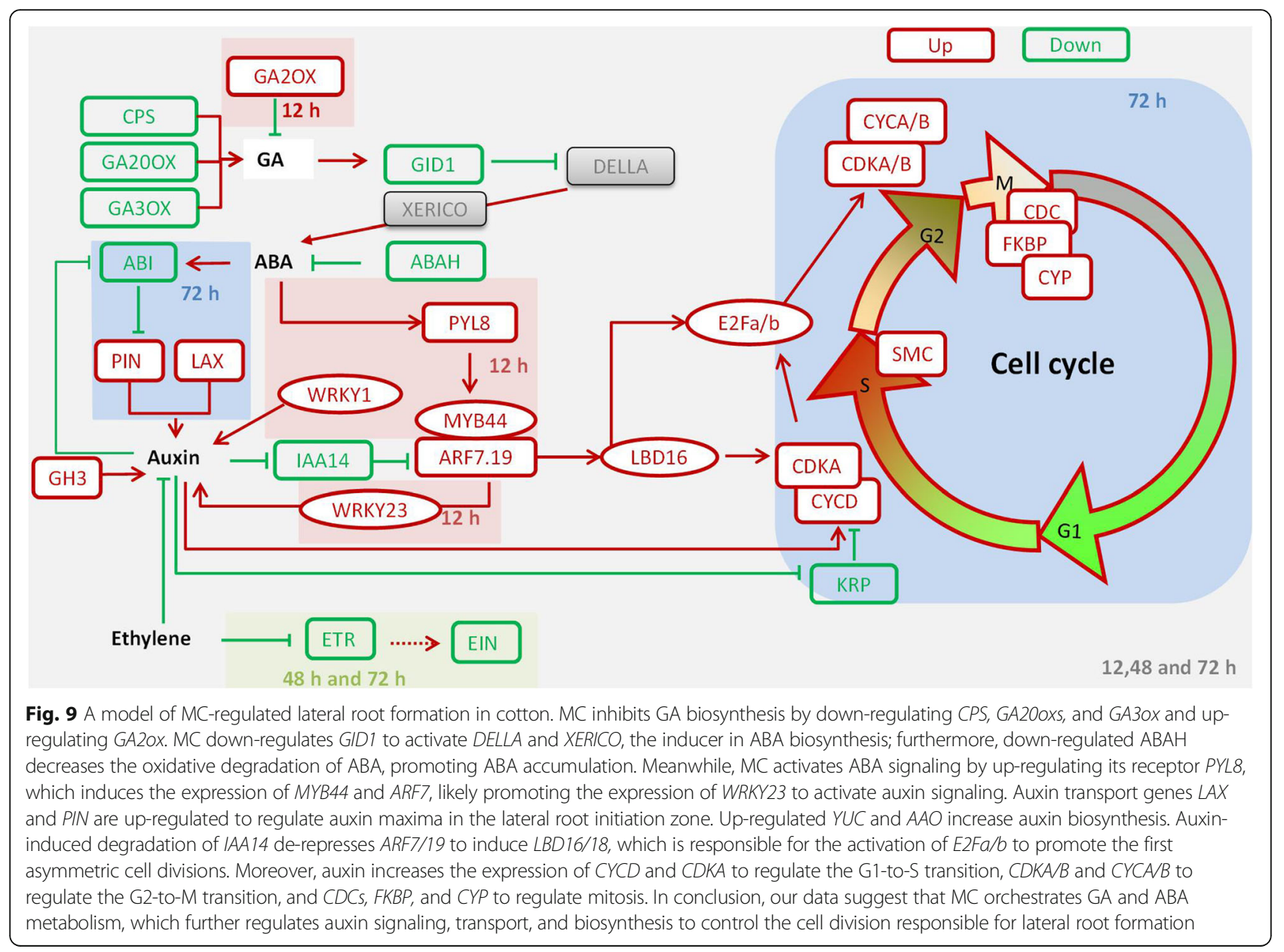

$\mathrm{cm}$ distance from the top of germination papers with an interval of $2.5 \mathrm{~cm}$. Three replicate germination boards (a total of 21 seeds) per cultivar. The germination boards were placed vertically in the germination tank with tap water to ensure germination papers retained moisture during the experiment process. The germination tank was placed at $25^{\circ} \mathrm{C}$ in darkness to promote germination. Once the seedlings grew beyond the top of the germination paper and unshelled the seed coat naturally, the tanks were removed to a customized growth room with $10 \mathrm{~h}$ light $/ 14 \mathrm{~h}$ dark at $(25 \pm 0.5 / 20 \pm 0.5)^{\circ} \mathrm{C}, 40-60 \%$ relative humidity, and $(400 \pm 30) \mu \mathrm{mol} \mathrm{m} \mathrm{m}^{-2} \mathrm{~s}^{-1}$ photosynthetically active radiation.

Images of the cotton seedlings on the germination paper were acquired at 12 DAT (days after soaking seed treatment) for Experiment 1, and were acquired at 6, 8, 10, 12, and 14 DAT for Experiment 2. The number of lateral roots were quantitatively calculated based on these images.

\section{Dynamic monitoring of root growth}

The dynamic effects of $\mathrm{MC}$ on root growth were monitored by using the customized high-throughput robotic platform RhizoChamber-Monitor [42]. Cotton seeds of K638 were pretreated by soaking in $400 \mathrm{mg} / \mathrm{L} \mathrm{MC} \mathrm{solu-}$ tion at $30^{\circ} \mathrm{C}$ for $12 \mathrm{~h}$, then rinsed with tap water and germinated in silver sand bed $(20 \mathrm{~cm}$ depth) for 3-4 days until emergence. Before transplanting, the sand was washed away carefully. Thirty-two seedlings per treatment were selected for transplanting. The seedlings were put carefully in the rhizoboxes [42]. The plants were irrigated at $1 \mathrm{~h}$ interval with $50 \pm 3 \mathrm{~mL}$ solution. Nutrient concentrations $(\mathrm{mM})$ were: $2.5 \mathrm{Ca}\left(\mathrm{NO}_{3}\right)_{2}, 1 \mathrm{MgSO}_{4}, 0.5$ $\left(\mathrm{NH}_{4}\right) \mathrm{H}_{2} \mathrm{PO}_{4}, \quad 2 \times 10^{-4} \quad \mathrm{CuSO}_{4}, \quad 1 \times 10^{-3} \mathrm{ZnSO}_{4}, \quad 0.1$ FeNaEDTA, $2 \times 10^{-2} \mathrm{H}_{3} \mathrm{BO}_{3}, 5 \times 10^{-6}\left(\mathrm{NH}_{4}\right)_{6} \mathrm{Mo}_{7} \mathrm{O}_{24}$, $1 \times 10^{-3} \mathrm{MnSO}_{4}$, and $0.1 \mathrm{mM} \mathrm{K} \mathrm{SO}_{4}$. The experiment was carried out in a customized growth room.

The root system of cotton seedlings were monitored for 12 days after transplanting (15 days after soaking treatment). Nine similar plants according to their root morphometry and the image quality were selected for each treatment. A customized image processing software, implemented in Matlab [42], was used to automatically extract the basic root-growth traits, including the total root area, total root length, primary root length, lateral roots length, and lateral root number. The lateral 
roots number along the different sections of primary root were extracted semi-automatically by using this software. Detailed information of the RhizoChamberMonitor system and the image processing software were given by Wu et al. [42].

\section{RNA extraction, CDNA library preparation, and sequencing for RNA-Seq}

Seeds of K638 were soaked in deionised water (Control) or $400 \mathrm{mg} / \mathrm{L} \mathrm{MC}$ solution at $30^{\circ} \mathrm{C}$ for $12 \mathrm{~h}$. Seedlings were then germinated using germination paper rolls and were placed at $25^{\circ} \mathrm{C}$ in darkness in a growth chamber. Seeds were germinated about $36 \mathrm{~h}$ after soaking seeds. The roots of -soaking-seed for 12,48 , and $72 \mathrm{~h}$ were subjected to RNA-seq analyses. The root tip region (0 to $4 \mathrm{~mm}$ from the root tip) and root middle region (4 to 20-40 $\mathrm{mm}$ from the root tip) were sampled separately, except for $12 \mathrm{~h}$ because the root was too short to separate. After harvest, samples were immediately frozen in liquid nitrogen and stored at $-80^{\circ} \mathrm{Cfor}$ RNA isolation. Three independent biological replicates were analyzed for each treatment. Around 30 roots per replicate were collected for sequencing.

Total RNA was extracted with the RNAprep Pure Plant Kit. RNA purity was checked using the NanoPhotometer spectrophotometer (IMPLEN, CA, USA). RNA integrity and quality were assessed by the Agilent RNA 6000 Nano Chip in the Agilent 2100 Bioanalyzer (Agilent Technologies, Santa Clara, CA, USA).

Two $\mu \mathrm{g}$ total RNA per sample was used as input material for the mRNA sample preparations. Sequencing libraries were generated using NEBNext UltraTM RNA Library Prep Kit for Illumina (NEB, USA) following manufacturer's recommendations and index codes were added to attribute sequences to each sample.

The clustering of the index-coded samples was performed on a cBot Cluster Generation System using TruSeq PE Cluster Kit v4-cBot-HS (Illumina) according to the manufacturer's instructions. After cluster generation, the library preparations were sequenced on an Illumina Hiseq 4000 platform and paired-end $150 \mathrm{bp}$ reads were generated.

\section{Statistical analysis of RNA-Seq Quality control}

Raw data (raw reads) of fastq format were firstly processed through in-house perl scripts. In this step, clean data (clean reads) were obtained by removing reads containing adapter and ploy- $\mathrm{N}$, and low quality reads from raw data. At the same time, Q20, Q30, GC-content and sequence duplication level of the clean data were calculated. All the downstream analyses were based on clean data with high quality.

Quantification of gene expression level.
Gene expression was normalized as FPKM (fragments per kilobase of exon model per million mapped reads) values [70]. HTSeq v0.5.3 (EMBL, Heidelberg, Germany) was used to count the reads numbers mapped to each gene. FPKM > 1 was used as the threshold to determine whether the gene was expressed in subsequent analysis.

Sample relationships were analyzed by a Principal component analysis (PCA) and hierarchical clustering. PCA was conducted by using the prcomp function in $\mathrm{R}$ with default settings. Hierarchical clustering of all samples was generated based on Pearson correlations. Euclidean algorithm-based K-means clustering was performed to generate the expression clusters of gene expression dynamics along three time points using the OmicShare tools (www.omicshare.com/ tools).

\section{Differential expression analysis}

Differential expression analysis of each two replicates was performed using the DESeq $\mathrm{R}$ package [71]. DESeq provide statistical routines for determining differential expression in digital gene expression data using a model based on the negative binomial distribution. The resulting $P$ values were adjusted using the Benjamini and Hochberg's approach for controlling the false discovery rate. Genes with an adjusted $P$-value $<0.05$ were assigned as differentially expressed.

GO and KEGG enrichment analysis of differentially expressed genes (DEGs).

Gene Ontology (GO) enrichment analysis of DEGs was implemented by the GOseq $\mathrm{R}$ packages based Wallenius non-central hyper-geometric distribution [72], which can adjust for gene length bias in DEGs. KEGG [73], a database resource for understanding high-level functions and utilities of the biological system, such as the cell, the organism, and the ecosystem at molecularlevel was generated by genome sequencing and other high-throughput experimental technologies (http://www. genome.jp/kegg/). We used KOBAS [74] software to test the statistical enrichment of DEGs in KEGG pathways.

\section{Quantitative real-time PCR (qRT-PCR) analysis}

cDNA synthesis was performed with Superscript II reverse transcriptase (Invitrogen) according to the manufacturer's instructions. qRT-PCR was performed using SYBR Green Master Mix. The reaction volume was $15 \mu \mathrm{l}$ which contained $1.5 \mu \mathrm{l}$ of diluted cDNA, $0.3 \mu \mathrm{l}$ of ROX reference dye, $0.3 \mu \mathrm{l}$ of each $10 \mu \mathrm{M}$ forward primer and reverse primer, and $7.5 \mu \mathrm{l}$ SYBR Premier Ex Taq mix (Takara, Japan). PCR amplification was performed using two-step cycling conditions of $95^{\circ} \mathrm{C}$ for $30 \mathrm{~s}$, followed by 40 cycles of $95^{\circ} \mathrm{C}$ for $5 \mathrm{~s}$ and $60^{\circ} \mathrm{C}$ for $35 \mathrm{~s}$. The levels of each gene transcript were calculated relative to its corresponding untreated control. Fold-changes of RNA transcripts were calculated by $\mathrm{C}_{\mathrm{T}}$ methods [75]. Twelve 
reference genes were selected for qRT-PCR analysis. The primers for each reference gene were listed in Additional file 5: Table S5.

\section{Endogenous hormonal level measurement}

Plant hormones, IAA, GA, and ABA in roots at five DAT, were extracted and purified according to the protocol described in Yang et al. [76]. Segments of approximately $2 \mathrm{~cm}$ root were cut and washed with deionized water. About $0.5 \mathrm{~g}$ of fresh roots was homogenized in $2 \mathrm{ml} 80 \%$ methanol and stored at $-20^{\circ} \mathrm{C}$ for 48 $\mathrm{h}$. The extract was centrifuged at $4000 \mathrm{~g}$ for $15 \mathrm{~min}$ at $4{ }^{\circ} \mathrm{C}$, and then the supernatant was passed through $\mathrm{C} 18$ Sep-Pak cartridges (Waters Corp., Millford, MA, USA). The sediments were re-suspended with $10 \mathrm{ml}$ of $100 \%$ $(\mathrm{v} / \mathrm{v})$ methanol and $10 \mathrm{ml}$ of ether. Afterwards, the eluate was dried down by pure $\mathrm{N} 2$ at $20^{\circ} \mathrm{C}$, and then stored at $-40^{\circ} \mathrm{C}$. The concentration of plant hormones was determined by ELISA technique following the protocol described in Zhao et al. [77]. Endogenous free IAA, GA, and ABA were calculated according to Weiler et al. [78].

\section{Supplementary information}

Supplementary information accompanies this paper at https://doi.org/10. 1186/s12870-019-2176-1.

Additional file 1: Table S1. Summary of sequence assembly after Illumina sequencing.

Additional file 2: Table S2. Statistics of genes in different expressionlevel interval.

Additional file 3: Table S3. GO annotation enrichment analysis for differentially expressed genes.

Additional file 4: Table S4. The list of ABA-, GA-, and ethylene-related differentially expressed genes

Additional file 5: Table S5. The primers for each reference gene for qRT-PCR analysis.

Additional file 6: Figure S1. The relationship of transcriptome samples. A. Principal component analysis (PCA) of Control and MC RNA-Seq samples at three time points after MC treatment; $B$. Hierarchical clustering of the RNA-Seq samples based on Pearson correlation. Height indicates the degree of variance of the $\mathrm{y}$-axis. Cotton seeds of $\mathrm{K} 638$ were treated with deionised water (Control) or $400 \mathrm{mg} / \mathrm{L} \mathrm{MC}$ for $12 \mathrm{~h}$. The roots at 12, 48, and $72 \mathrm{~h}$ after treatment were subjected to RNA-seq analyses. "R" indicates the whole root, " $\mathrm{M}$ " indicates the root middle region (4 to 20-40 $\mathrm{mm}$ from the root tip), and "T" indicates the root tip region (0 to $4 \mathrm{~mm}$ from the root tip).

Additional file 7: Figure S2. The functional annotation and $\mathrm{GO}$ enrichment of the down-regulated and up-regulated DEGs at each time point for root middle region and root tip.

Additional file 8: Figure S3. Statistical analyses of functional enrichments by KEGG pathways. Values in boxes are the number of enriched genes, values in boxes and in brackets are $P$-value $(0$ stands for $P<0.01)$

Additional file 9: Figure S4. Up-regulated and down-regulated hormone-related DEGs upon MC treatment. Cotton seeds of K638 were treated with deionised water (Control) or $400 \mathrm{mg} / \mathrm{L}$ MC soaking-seed for $12 \mathrm{~h}$. The DEGs were collected with FDR $<5 \%$.

Additional file 10: Figure S5. Up-regulated and down-regulated cell cycle/division-related DEGs upon MC treatment that belonged to different genes family, including CDC, CDK, Cyclin, KRP, CYP, FKBP and SMC.
Cotton seeds of K638 were treated with deionised water (Control) or 400 $\mathrm{mg} / \mathrm{L} \mathrm{MC}$ for $12 \mathrm{~h}$. The DEGs were collected at $72 \mathrm{~h}$ after MC treatment in the root middle region (FDR $<5 \%$ )

Additional file 11: Figure S6. The relative expression pattern of auxinand cell cycle-related genes. A. The dynamics expression of auxin biosynthesis and transport genes in Control and MC. B. Relative transcript levels of genes corresponding to A by qRT-PCR. C. The relative expression of auxin- and cell cycle-related genes in Control and MC. D. Relative transcript levels of genes corresponding to $C$ by qRT-PCR.

\section{Abbreviations}

BZL/PL: Branching zone length /Primary root length; DAT: Days after soaking seed treatment; DEGs: Differentially expressed genes; FPKM: Fragments per kilobase of exon model per million mapped reads; MC: Mepiquat chloride; PCA: Principal component analysis

\section{Acknowledgments}

We thank Xiaolei Zhang and Sai Wang for their help in performing the experiments. We thank Dr. Kevin L. Cox Jr. for critical reading of the manuscript.

\section{Authors' contributions}

$\mathrm{ZL}, \mathrm{XT}$ and FL conceived and designed the study; QW and QW carried out the experiments; QW, MD, JW, NW, BW analyzed and interpreted the data; QW, FL and XT prepared the manuscript. All authors read and approved the final version of manuscript.

\section{Funding}

This work was funded by the National Key Research and Development Project (SQ2018YFD100007) to Zhaohu Li, the China Postdoctoral Science Foundation (2017 M620960) to Q.W., and Science and Technology Projects of Xinjiang Production and Construction Corps (2018AB039) to Mingwei Du.

Availability of data and materials

The datasets supporting the conclusions of this article are available in https://github.com/wuqiangithub/MC_Root_RNA-seq.

Ethics approval and consent to participate

Not applicable.

Consent for publication

Consent and approval for publication was obtained from all authors.

\section{Competing interests}

The authors declare that they have no competing interests.

\section{Author details}

${ }^{1}$ College of Agronomy and Biotechnology, China Agricultural University, Beijing 100193, China. ${ }^{2}$ Institute of Agricultural Information, Jiangsu Academy of Agricultural Sciences, Nanjing 210014, China. ${ }^{3}$ Plant Phenomics Research Center, State Key Laboratory of Crop Genetics and Germplasm Enhancement, Nanjing Agricultural University, Nanjing 210095, China. ${ }^{4}$ Institute of Cotton Research of Chinese Academy of Agricultural Sciences, Anyang 455000, Henan, China.

Received: 22 August 2019 Accepted: 29 November 2019

Published online: 21 December 2019

References

1. Forde $B$, Lorenzo $H$. The nutritional control of root development. Plant Soil. 2001;232:51-68.

2. Osmont KS, Sibout R, Hardtke CS. Hidden branches: developments in root system architecture. Annu Rev Plant Biol. 2007:58:93-113.

3. Varney G, Canny M, Wang X, McCully M. The branch roots of Zea. I. First order branches, their number, sizes and division into classes. Ann Bot. 1991; 67:357.

4. Lecompte F, Pagès L. Apical diameter and branching density affect lateral root elongation rates in banana. Environ Exp Bot. 2007;59:243-51. 
5. Benková E, Michniewicz M, Sauer M, Teichmann T, Seifertová D, Jürgens G, et al. Local, efflux-dependent Auxin gradients as a common module for plant organ formation. Cell. 2003;115:591-602.

6. Smet ID, Tetsumura T, Rybel BD, dit Frey NF, Laplaze L, Casimiro I, et al. Auxin-dependent regulation of lateral root positioning in the basal meristem of Arabidopsis. Development. 2007;134:681-90.

7. Lucas M, Godin C, Jay-Allemand C, Laplaze L. Auxin fluxes in the root apex co-regulate gravitropism and lateral root initiation. J Exp Bot. 2008;59:55-66.

8. Dubrovsky JG, Sauer M, Napsucialy-Mendivil S, Ivanchenko MG, Friml J, Shishkova S, et al. Auxin acts as a local morphogenetic trigger to specify lateral root founder cells. PNAS. 2008;105:8790-4

9. Petersson SV, Johansson Al, Kowalczyk M, Makoveychuk A, Wang JY, Moritz T, et al. An Auxin gradient and maximum in the Arabidopsis root apex shown by high-resolution cell-specific analysis of IAA distribution and synthesis. Plant Cell. 2009;21:1659-68.

10. Yu P, Eggert K, Wirén N, von Li C, Hochholdinger F. Cell-type specific gene expression analyses by RNA-Seq reveal local high nitrate triggered latera root initiation in shoot-borne roots of maize by modulating auxin-related cell cycle-regulation. Plant Physiol. 2015;169:690-704 00888.2015.

11. Himanen K, Boucheron E, Vanneste S, de Almeida Engler J, Inzé D, Beeckman T. Auxin-Mediated Cell Cycle Activation during Early Lateral Root Initiation. Plant Cell. 2002;14:2339-51.

12. Ren H, Santner A, Del JP, Murray JA, Estelle M. Degradation of the cyclindependent kinase inhibitor KRP1 is regulated by two different ubiquitin E3 ligases. Plant J. 2008;53:705-16.

13. Nieuwland J, Scofield S, Murray JAH. Control of division and differentiation of plant stem cells and their derivatives. Semin Cell Dev Biol. 2009:20:1134-42.

14. Sanz L, Dewitte W, Forzani C, Patell F, Nieuwland J, Wen B, et al. The Arabidopsis D-Type Cyclin CYCD2;1 and the Inhibitor ICK2/KRP2 Modulate Auxin-Induced Lateral Root Formation. Plant Cell. 2011:23:641-60 tpc.110. 080002.

15. Vanneste S, Coppens F, Lee E, Donner TJ, Xie Z, Isterdael GV, et al. Developmental regulation of CYCA2s contributes to tissue-specific proliferation in Arabidopsis. EMBO J. 2011;30:3430-41.

16. Marchant A, Bhalerao R, Casimiro I, Eklöf J, Casero PJ, Bennett M, et al. AUX1 promotes lateral root formation by facilitating Indole-3-acetic acid distribution between sink and source tissues in the Arabidopsis seedling Plant Cell. 2002;14:589-97.

17. Marhavý P, Vanstraelen M, Rybel BD, Zhaojun D, Bennett MJ, Beeckman T, et al. Auxin reflux between the endodermis and pericycle promotes lateral root initiation. EMBO J. 2013;32:149-58.

18. Marhavý P, Duclercq J, Weller B, Feraru E, Bielach A, Offringa R, et al. Cytokinin controls polarity of PIN1-dependent Auxin transport during lateral root organogenesis. Curr Biol. 2014;24:1031-7.

19. de Billy F, Grosjean C, May S, Bennett M, Cullimore JV. Expression studies on AUX1-like genes in Medicago truncatula suggest that Auxin is required at two steps in early nodule development. MPMI. 2001:14:267-77.

20. Taylor-Teeples M, Lanctot A, Nemhauser JL. As above, so below: Auxin's role in lateral organ development. Dev Biol. 2016;419:156-64.

21. Fukaki H, Tameda S, Masuda H, Tasaka M. Lateral root formation is blocked by a gain-of-function mutation in the SOLITARY-ROOT/IAA14 gene of Arabidopsis. Plant J. 2002;29:153-68.

22. Okushima Y, Overvoorde PJ, Arima K, Alonso JM, Chan A, Chang C, et al. Functional genomic analysis of the AUXIN RESPONSE FACTOR gene family members in Arabidopsis thaliana: unique and overlapping functions of ARF7 and ARF19. Plant Cell. 2005;17:444-63.

23. Du Y, Scheres B. Lateral root formation and the multiple roles of auxin. Exp Bot. 2018;69:155-67.

24. Lavenus J, Goh T, Guyomarc'h S, Hill K, Lucas M, Voß U, et al. Inference of the Arabidopsis lateral root gene regulatory network suggests a bifurcation mechanism that defines Primordia flanking and central zones. Plant Cell. 2015;27:1368-88

25. Stoeckle D, Thellmann M, Vermeer JE. Breakout-lateral root emergence in Arabidopsis thaliana. Curr Opin Plant Biol. 2018:41:67-72.

26. Okushima Y, Fukaki H, Onoda M, Theologis A, Tasaka M. ARF7 and ARF19 regulate lateral root formation via direct activation of $L B D / A S L$ genes in Arabidopsis. Plant Cell. 2007;19:118-30.

27. Berckmans B, Vassileva V, Schmid SPC, Maes S, Parizot B, Naramoto S, et al, Auxin-dependent cell cycle reactivation through transcriptional regulation of Arabidopsis E2Fa by lateral organ boundary proteins. Plant Cell. 2011;23: 3671-83.
28. Gou J, Strauss SH, Tsai CJ, Fang K, Chen Y, Jiang X, et al. Gibberellins regulate lateral root formation in Populus through interactions with Auxin and other hormones. Plant Cell. 2010;22:623-39.

29. Shin R, Burch AY, Huppert KA, Tiwari SB, Murphy AS, Guilfoyle TJ, et al. The Arabidopsis transcription factor MYB77 modulates Auxin signal transduction. Plant Cell. 2007;19:2440-53.

30. Zhao Y, Xing L, Wang X, Hou Y-J, Gao J, Wang P, et al. The ABA Receptor PYL8 Promotes Lateral Root Growth by Enhancing MYB77-Dependent Transcription of Auxin-Responsive Genes. Sci Signal. 2014;7:ra53.

31. Shkolnik-Inbar D, Bar-Zvi D. ABI4 Mediates Abscisic Acid and Cytokinin Inhibition of Lateral Root Formation by Reducing Polar Auxin Transport in Arabidopsis. Plant Cell. 2010;22:3560-73 tpc.110.074641

32. Negi S, Ivanchenko MG, Muday GK. Ethylene regulates lateral root formation and auxin transport in Arabidopsis thaliana. Plant J. 2008;55:175-87.

33. Singh $M$, Gupta A, Laxmi A. Ethylene acts as a negative regulator of glucose induced lateral root emergence in Arabidopsis. Plant Signal Behav. 2015;10: e1058460

34. Sun J, Xu Y, Ye S, Jiang H, Chen Q, Liu F, et al. Arabidopsis ASA1 is important for Jasmonate-mediated regulation of Auxin biosynthesis and transport during lateral root formation. Plant Cell. 2009;21:1495-511.

35. Sun J, Chen Q, Qi L, Jiang H, Li S, Xu Y, et al. Jasmonate modulates endocytosis and plasma membrane accumulation of the Arabidopsis PIN2 protein. New Phytol. 2011;191:360-75.

36. Rademacher W. Growth Retardants: effects on gibberellin biosynthesis and other metabolic pathways. Annu Rev Plant Physiol Plant Mol Biol. 2000;51:501-31.

37. de Almeida $A Q$, Rosolem CA. Cotton root and shoot growth as affected by application of mepiquat chloride to cotton seeds. Acta Sci Agronomy. 2012; 34:61-5.

38. Reddy VR, Baker DN, Hodges HF. Temperature and Mepiquat chloride effects on cotton canopy architecture. Agron J. 1990;82:190-5.

39. Yang F, Du M, Tian X, Eneji AE, Duan L, Li Z. Plant growth regulation enhanced potassium uptake and use efficiency in cotton. Field Crop Res. 2014;163:109-18.

40. Wang L, Mu C, Du M, Chen Y, Tian X, Zhang M, et al. The effect of mepiquat chloride on elongation of cotton (Gossypium hirsutum L.) internode is associated with low concentration of gibberellic acid. Plant Sci. 2014;225:15-23

41. Gu S, Evers JB, Zhang L, Mao L, Zhang S, Zhao X, et al. Modelling the structural response of cotton plants to mepiquat chloride and population density. Ann Bot. 2014;114:877-87.

42. Wu J, Wu Q, Pagès $L$, Yuan $Y$, Zhang $X$, Du M, et al. RhizoChamber-monitor: a robotic platform and software enabling characterization of root growth. Plant Methods. 2018;14. https://doi.org/10.1186/s13007-018-0316-5.

43. Tsukagoshi H, Busch W, Benfey PN. Transcriptional regulation of ROS controls transition from proliferation to differentiation in the root. Cell. 2010; 143:606-16.

44. Berova M, Zlatev Z. Physiological response and yield of paclobutrazol treated tomato plants (Lycopersicon esculentum Mill). Plant Growth Regul. 2000;30:117-23.

45. Saraiva Grossi JA, de Moraes PJ, de Araújo TS, Barbosa JG, Finger FL, Cecon PR. Effects of paclobutrazol on growth and fruiting characteristics of 'pitanga' ornamental pepper. Acta Hortic. 2005;683:333-6.

46. Watson G. Effect of transplanting and Paclobutrazol on root growth of 'green column' black maple and 'summit' green ash. J Environ Hortic. 2004; 22:209-12.

47. Busov V, Meilan R, Pearce DW, Rood SB, Ma C, Tschaplinski TJ, et al. Transgenic modification of gai or rgl1 causes dwarfing and alters gibberellins, root growth, and metabolite profiles in Populus. Planta. 2006; 224:288-99.

48. Ariizumi T, Hauvermale AL, Nelson SK, Hanada A, Yamaguchi S, Steber CM. Lifting DELLA repression of Arabidopsis seed germination by Nonproteolytic gibberellin signaling. Plant Physiol. 2013;162:2125-39.

49. Mashiguchi K, Tanaka K, Sakai T, Sugawara S, Kawaide H, Natsume M, et al. The main auxin biosynthesis pathway in Arabidopsis. PNAS. 2011;108:18512-7.

50. Rogg LE, Lasswell J, Bartel B. A gain-of-function mutation in IAA28 suppresses lateral root development. Plant Cell. 2001:13:465-80.

51. Tatematsu K, Kumagai S, Muto H, Sato A, Watahiki MK, Harper RM, et al. MASSUGU2 encodes aux/IAA19, an Auxin-regulated protein that functions together with the transcriptional activator NPH4/ARF7 to regulate differential growth responses of hypocotyl and formation of lateral roots in Arabidopsis thaliana. Plant Cell. 2004;16:379-93. 
52. Uehara T, Okushima Y, Mimura T, Tasaka M, Fukaki H. Domain II mutations in CRANE/IAA18 suppress lateral root formation and affect shoot development in Arabidopsis thaliana. Plant Cell Physiol. 2008;49:1025-38.

53. De Rybel B, Vassileva V, Parizot B, Demeulenaere M, Grunewald W, Audenaert D, et al. A novel aux/IAA28 signaling Cascade activates GATA23dependent specification of lateral root founder cell identity. Curr Biol. 2010; 20:1697-706.

54. Inukai Y, Sakamoto T, Ueguchi-Tanaka M, Shibata Y, Gomi K, Umemura I, et al. Crown rootless1, which is essential for crown root formation in Rice, is a target of an AUXIN RESPONSE FACTOR in Auxin signaling. Plant Cell. 2005; 17:1387-96.

55. Taramino G, Sauer M, JLS J, Multani D, Niu X, Sakai H, et al. The maize (Zea mays L.) RTCS gene encodes a LOB domain protein that is a key regulator of embryonic seminal and post-embryonic shoot-borne root initiation. Plant J. 2007:50:649.

56. Péret B, De Rybel B, Casimiro I, Benková E, Swarup R, Laplaze L, et al. Arabidopsis lateral root development: an emerging story. Trends Plant Sci. 2009;14:399-408.

57. Lee HW, Kim NY, Lee DJ, Kim J. LBD18/ASL20 regulates lateral root formation in combination with LBD16/ASL18 downstream of ARF7 and ARF19 in Arabidopsis. Plant Physiol. 2009;151:1377-89.

58. Feng Z, Zhu J, Du X, Cui X. Effects of three auxin-inducible LBD members on lateral root formation in Arabidopsis thaliana. Planta. 2012;236:1227-37.

59. Magyar Z, Veylder LD, Atanassova A, Bakó L, Inzé D, Bögre L. The role of the Arabidopsis E2FB transcription factor in regulating Auxin-dependent cell division. Plant Cell. 2005:17:2527-41.

60. Sozzani R, Maggio C, Varotto S, Canova S, Bergounioux C, Albani D, et al. Interplay between Arabidopsis activating factors E2Fb and E2Fa in cell cycle progression and development. Plant Physiol. 2006;140:1355-66.

61. Polyn S, Willems A, De Veylder L. Cell cycle entry, maintenance, and exit during plant development. Curr Opin Plant Biol. 2015;23:1-7.

62. Himanen $\mathrm{K}$, Vuylsteke $\mathrm{M}$, Vanneste $\mathrm{S}$, Vercruysse $\mathrm{S}$, Boucheron $\mathrm{E}$, Alard $\mathrm{P}$, et al. Transcript profiling of early lateral root initiation. Proc Natl Acad Sci U S A. 2004;101:5146-51.

63. Riou-Khamlichi C, Huntley R, Jacqmard A, Murray JAH. Cytokinin activation of Arabidopsis cell division through a D-type Cyclin. Science. 1999;283: 1541-4.

64. Francis D, Sorrell DA. The interface between the cell cycle and plant growth regulators: a mini review. Plant Growth Regul. 2001;33:1-12.

65. Perrot-Rechenmann C. Cellular Responses to Auxin: Division versus Expansion. Cold Spring Harb Perspect Biol. 2010;2:a001446.

66. Hopwood B, Dalton S. Cdc45p assembles into a complex with Cdc46p/ Mcm5p, is required for minichromosome maintenance, and is essential for chromosomal DNA replication. Proc Natl Acad Sci U S A. 1996;93: 12309-14.

67. Zou L, Mitchell J, Stillman B. CDC45, a novel yeast gene that functions with the origin recognition complex and $\mathrm{mcm}$ proteins in initiation of DNA replication. Mol Cell Biol. 1997;17:553-63.

68. Lu KP, Liou Y-C, Zhou XZ. Pinning down proline-directed phosphorylation signaling. Trends Cell Biol. 2002;12:164-72

69. Yazdi PT, Wang Y, Zhao S, Patel N, Lee EY-HP, Qin J. SMC1 is a downstream effector in the ATM/NBS1 branch of the human S-phase checkpoint. Genes Dev. 2002:16:571-82

70. Mortazavi A, Williams BA, McCue K, Schaeffer L, Wold B. Mapping and quantifying mammalian transcriptomes by RNA-Seq. Nat Methods. 2008:5: 621-8.

71. Anders S, Huber W. Differential expression analysis for sequence count data. Genome Biol. 2010;11:R106.

72. Young MD, Wakefield MJ, Smyth GK, Oshlack A. Gene ontology analysis for RNA-seq: accounting for selection bias. Genome Biol. 2010;11:R14.

73. Kanehisa M, Araki M, Goto S, Hattori M, Hirakawa M, Itoh M, et al. KEGG for linking genomes to life and the environment. Nucleic Acids Res. 2008; 36(suppl_1):D480-4

74. Mao X, Cai T, Olyarchuk JG, Wei L. Automated genome annotation and pathway identification using the KEGG Orthology (KO) as a controlled vocabulary. Bioinformatics. 2005;21:3787-93.

75. Livak KJ, Schmittgen TD. Analysis of relative gene expression data using realtime quantitative $P C R$ and the $2-\Delta \Delta C T$ method. Methods. 2001;25:402-8.

76. Yang J, Zhang J, Wang Z, Zhu Q, Wang W. Hormonal changes in the grains of Rice subjected to water stress during grain filling. Plant Physiol. 2001;127: $315-23$.
77. Zhao J, Li G, Yi G-X, Wang B-M, Deng A-X, Nan T-G, et al. Comparison between conventional indirect competitive enzyme-linked immunosorbent assay (icELISA) and simplified icELISA for small molecules. Anal Chim Acta. 2006:571:79-85.

78. Weiler EW, Jourdan PS, Conrad W. Levels of indole-3-acetic acid in intact and decapitated coleoptiles as determined by a specific and highly sensitive solid-phase enzyme immunoassay. Planta. 1981;153:561-71.

\section{Publisher's Note}

Springer Nature remains neutral with regard to jurisdictional claims in published maps and institutional affiliations.
Ready to submit your research? Choose BMC and benefit from:

- fast, convenient online submission

- thorough peer review by experienced researchers in your field

- rapid publication on acceptance

- support for research data, including large and complex data types

- gold Open Access which fosters wider collaboration and increased citations

- maximum visibility for your research: over $100 \mathrm{M}$ website views per year

At BMC, research is always in progress.

Learn more biomedcentral.com/submissions 